\title{
Biological rationale for the use of DNA methyltransferase inhibitors as new strategy for modulation of tumor response to chemotherapy and radiation
}

Giovanni L Gravina ${ }^{1,2^{*}}$, Claudio Festuccia ${ }^{2}$, Francesco Marampon ${ }^{1,2,3}$, Vladimir M Popov ${ }^{3}$, Richard G Pestell ${ }^{3}$, Bianca M Zani ${ }^{2}$, Vincenzo Tombolini ${ }^{1,2}$

\begin{abstract}
Epigenetic modifications play a key role in the patho-physiology of many tumors and the current use of agents targeting epigenetic changes has become a topic of intense interest in cancer research. DNA methyltransferase (DNMT) inhibitors represent a promising class of epigenetic modulators. Research performed yielded promising anti-tumorigenic activity for these agents in vitro and in vivo against a variety of hematologic and solid tumors. These epigenetic modulators cause cell cycle and growth arrest, differentiation and apoptosis. Rationale for combining these agents with cytotoxic therapy or radiation is straightforward since the use of DNMT inhibitor offers greatly improved access for cytotoxic agents or radiation for targeting DNA-protein complex. The positive results obtained with these combined approaches in preclinical cancer models demonstrate the potential impact DNMT inhibitors may have in treatments of different cancer types. Therefore, as the emerging interest in use of DNMT inhibitors as a potential chemo- or radiation sensitizers is constantly increasing, further clinical investigations are inevitable in order to finalize and confirm the consistency of current observations.

The present article will provide a brief review of the biological significance and rationale for the clinical potential of DNMT inhibitors in combination with other chemotherapeutics or ionizing radiation. The molecular basis and mechanisms of action for these combined treatments will be discussed herein.
\end{abstract}

A significant number of tumors are classified as poorly or non-responsive to therapeutic drugs or radiotherapy. Increasing the chemotherapeutic dosage or radiation dose not only fails in improving the therapeutic response, but it also contributes to the development of side effects and resistance to therapy. An ideal strategy would consist of the identification of anticancer agents able to act synergistically with standard treatments such as radiotherapy and chemotherapy, which would result in triggering the cell death preferentially in tumor cells. Many patients with neoplastic diseases exhibit hypermethylation of cytosine residues in gene promoters which induce silencing of key tumor suppressor genes.

\footnotetext{
* Correspondence: giovanniluca.gravina@poste.it

'Department of Experimental Medicine, Division of Radiation Oncology, S. Salvatore Hospital, L'Aquila, University of L'Aquila, Medical School, L'Aquila 67100, Italy

Full list of author information is available at the end of the article
}

Since methylation of $\mathrm{CpG}$ islands occurs infrequently in normal cells, the modulation of this post-translational modification may provide a selective tumor-specific therapeutic target.

The packaging of DNA is critical for many DNA metabolic processes including transcription, replication and DNA repair. DNA is normally tightly wrapped around histone octamers to form nucleosomes. These primary elements have been traditionally thought as stable DNA packaging units. However, it is now evident that they are dynamic structures that can be altered by different molecular processes [1-3]. These include (i) incorporation of histone variants, which are thought to have specialized functions [4], (ii) replacement, repositioning or, in certain cases, the removal of nucleosomes by chromatin remodeling complexes, and finally (iii) post-translational modifications. 
Post-translational modifications include (i) lysine acetylation and deacetylation, (ii) methylation, (iii) serine phosphorylation and ubiquination and (iv) lysine sumoylation. These modifications play a major role in modeling higher-order chromatin conformation and modifying the DNA accessibility to transcription factors $[5,6]$. Therefore, such changes are not strictly "genetic," even though the specific chromatin patterns are usually inherited by daughter cells during replication.

In cancer, epigenetic silencing through methylation occurs just as frequently as mutations or deletions and leads to aberrant silencing of genes with tumor-suppressor functions [2,3].

Among the post-translational processes, DNA methylation is one of the most extensively characterized epigenetic modifications and its biological role is to maintain DNA transcriptionally quiescent, resulting in gene silencing (Figure 1) [7-9]. This process is dependent upon the action of DNA methyltransferases (DNMTs), enzymes that catalyze the addition of methyl groups to the $5^{\prime}$ carbon of the cytosine residues (Figure 1) [7]. Several isoforms of DNMTs are present in normal cells as well as in tumor cells [9-11]. Existing evidence indicates that DNMT1 appears to be responsible for maintenance of established patterns of methylated DNA, while DNMT-3a and $-3 \mathrm{~b}$ seem to mediate de novo DNA methylation patterns [9-11]. Interestingly DNMT1 alone is not sufficient for maintenance of abnormal gene hypermethylation but the cooperation with DNMT3b must occur for this function [12-14]. In the last years many different DNMT inhibitors have been developed (Table 1) and multiple molecular mechanisms by which

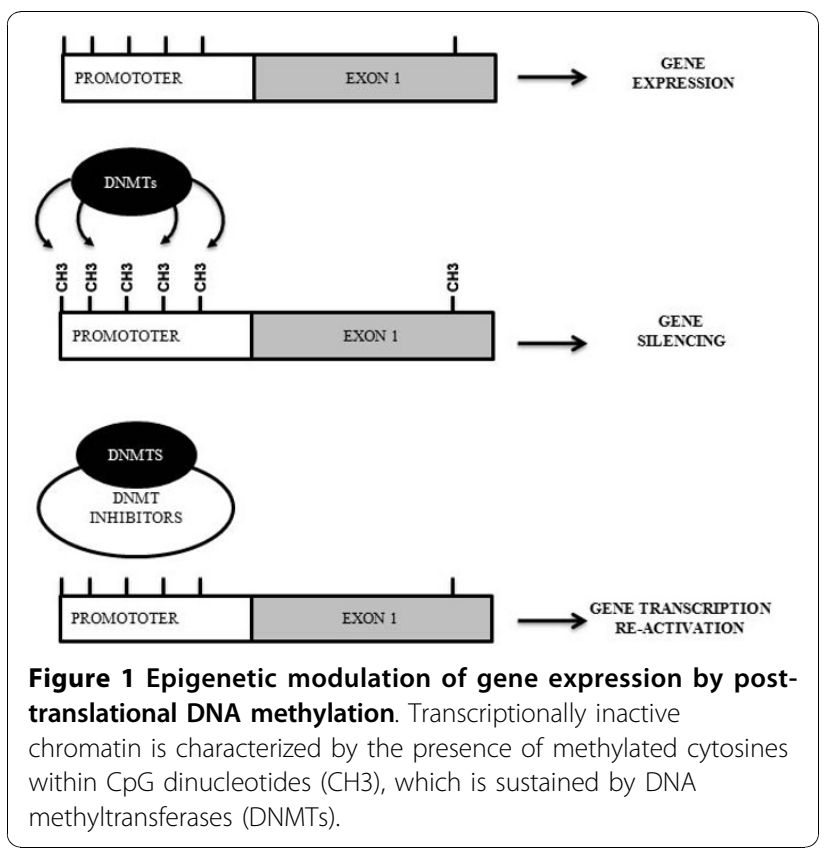

DNMT inhibitors induce anti-cancer effects have been identified. These mechanisms are partially mediated by the hypomethylation of DNA with cytotoxic effects documented at higher concentrations $[8,15]$. The net effect is the modulation of specific genes involved in cellular processes such as apoptosis, cytostasis, differentiation and tumor angiogenesis $[8,15]$. Therefore, it is not surprising that DNMT inhibitors are emerging as promising class of drugs in cancer treatment, especially in combination with other agents or with other treatments like radiotherapy. Even though some DNMT inhibitors have entered into clinical trials, we currently have limited understanding of their precise mechanisms of action, especially when combined with other available treatments.

The present article will provide a brief review of the biological significance and scientific rationale for the clinical potential of DNMT inhibitors in combination with chemotherapy or radiotherapy.

\section{Combined therapy: Published Experience, Ongoing Studies and Future directions}

The goal of combining different treatments in the management of cancer is to increase and prolong the response rate as well as to decrease the toxicity associated with each treatment. Two different strategies can be utilized to achieve these objectives. Treatments may be combined based on the absence of overlapping or synergistic toxicities leading to empiric combinations. A more sound approach is based upon the combination of treatments with known convergent molecular mechanisms.

It is well known that epigenetic abnormalities in cancer affect a plethora of genes involved in key cellular pathways including cell cycle control, apoptosis, immune recognition, angiogenesis tumor invasion and metastasis. Consistent with the functional diversification of epigenetic alterations, epigenetic drugs are characterized by pleiotropic effects which affect key aspects of tumor biology leading to an overall impairment of the neoplastic potential of tumor cells. These are the reasons that constitute the rationale for the proposed usage of DNMT inhibitors as anticancer agents, alone or in combination with other treatments.

\section{DNMT inhibitors and chemotherapy}

Despite the promising anticancer activity in haematological malignancies [16], early clinical trials showed that DNMT inhibitors have low anticancer activity and significant toxicity as single agent in solid tumors. Recent studies, however, suggest that low concentrations of DNMT inhibitors such as 5-Aza and decitabine may act synergistically when combined with chemotherapy and contribute to overcoming intrinsic or acquired 
Table 1 Overview of some DNMT inhibitors with their mechanisms of action

\begin{tabular}{|c|c|c|}
\hline Name & Chemical nature & Mechanism of action \\
\hline Azacitidine & $\begin{array}{l}\text { Ribonucleoside } \\
\text { analogue }\end{array}$ & $\begin{array}{l}\text { This drug is a ribonucleoside analogue and it binds to RNA and DNA. This molecule interrupts mRNA } \\
\text { translation and when incorporated into DNA inhibits methylation by trapping DNMTs. At relatively } \\
\text { higher concentrations this drug results in the formation of high levels of enzyme-DNA adducts. }\end{array}$ \\
\hline Decitabine & $\begin{array}{l}\text { Deoxyribonucleoside } \\
\text { analogue }\end{array}$ & $\begin{array}{l}\text { This drug is a deoxyribonucleoside analogue. For this reason, this molecule does not bind to RNA but } \\
\text { only to DNA. When incorporated into DNA inhibits methylation by trapping DNMTs resulting in the } \\
\text { reduced methylation of cytosines in DNA synthesized after drug treatment. When used at relatively } \\
\text { high concentrations this drug results in the formation of high levels of enzyme-DNA adducts, }\end{array}$ \\
\hline Zebularine & $\begin{array}{l}\text { Deoxyribonucleoside } \\
\text { analogue }\end{array}$ & $\begin{array}{l}\text { This drug is a deoxyribonucleoside analogue. For this reason, this molecule does not bind to RNA but } \\
\text { only to DNA. When incorporated into DNA inhibits methylation by trapping DNMTs resulting in the } \\
\text { reduced methylation of cytosines in DNA synthesized after drug treatment. When used at relatively } \\
\text { high concentrations this drug results in the formation of high levels of enzyme-DNA adducts, }\end{array}$ \\
\hline $\begin{array}{l}\text { (-)-epigallocatechin- } \\
\text { 3-gallate }\end{array}$ & $\begin{array}{l}\text { Non-nucleoside } \\
\text { analogue }\end{array}$ & \\
\hline MG98 & $\begin{array}{l}\text { Non-nucleoside } \\
\text { analogue }\end{array}$ & $\begin{array}{l}\text { This antisense oligonucleotide targets the } 3 \text { UTR of DNMT1 causing a methylation decrease in cell } \\
\text { lines and animal models }\end{array}$ \\
\hline RG108 & $\begin{array}{l}\text { Non-nucleoside } \\
\text { analogue }\end{array}$ & $\begin{array}{l}\text { This small molecule is not incorporated into DNA but i bind to the catalytic site of DNMTs causing } \\
\text { inhibition of DNA methylation }\end{array}$ \\
\hline Procainamide & $\begin{array}{l}\text { Non-nucleoside } \\
\text { analogue }\end{array}$ & $\begin{array}{l}\text { This molecule reduces DNMT1's affinity } \\
\text { for both DNA and S-adenosyl-methionine causing a decrease in DNA methylation }\end{array}$ \\
\hline
\end{tabular}

chemoresistance [17-19]. These properties are considered clinically significant as the resistance of tumor cells to cytotoxic agents remains the major obstacle in chemotherapeutic-based treatments. The mechanisms underlying chemoresistance remain in some measure elusive even though multifactorial mechanisms, including epigenetic modifications may drive this mechanism [20-25]. Therefore, any effort to overcome multi-drug resistance represents the primary goal in cancer research. Based on the chemical mechanisms, DNMT inhibitors act through different mechanisms. Among the different mechanisms postulated, alterations in differentiation, changes in apoptosis, and induction of a beneficial immune response are considered of main importance [19]. Finally, the induction of DNA damage due to the formation of irreversible covalent enzymeDNA adducts has also been taken into consideration.

\section{Cell signaling}

Cell signaling is a complex system of communication that coordinates basic cellular activities. Cells perceive and correctly respond to microenvironment via this complex system engaging in cellular processes such as, tissue repair, immunity, as well as normal tissue homeostasis. Errors in cell signaling are involved in the development as well as in the progression of cancer and aberrant DNMT activity has been involved in these processes. PTEN (phosphatase and tensin homolog deleted on chromosome ten) is a tumor suppressor gene and its functional loss has been documented in bladder cancer, glioblastoma, melanoma and cancers of the prostate, breast, lung and thyroid [26-30]. This tumor suppressor gene controls PI3K by preventing the activation of PDK-
1 and Akt (Figure 2). The functional loss of PTEN is higher than that attributable to $\mathrm{LOH}$ of chromosome $10 \mathrm{q}$ and post-translational mechanisms, including hypermethylation, explain the other part of this phenomenon [31-34]. Evidence indicates that 5-Aza is a chemosensitizer in prostate cancer [35] and its property seems mediated by PTEN. After infection with a recombinant adenovirus containing wild-type PTEN, bladder tumor cells acquire greater chemosensitivity to the cytotoxic effect of doxorubicin [36-39]. The chemosensitivity induced by PTEN is partially mediated by PI3K and Akt/PKB [40]. Other evidence, in a different

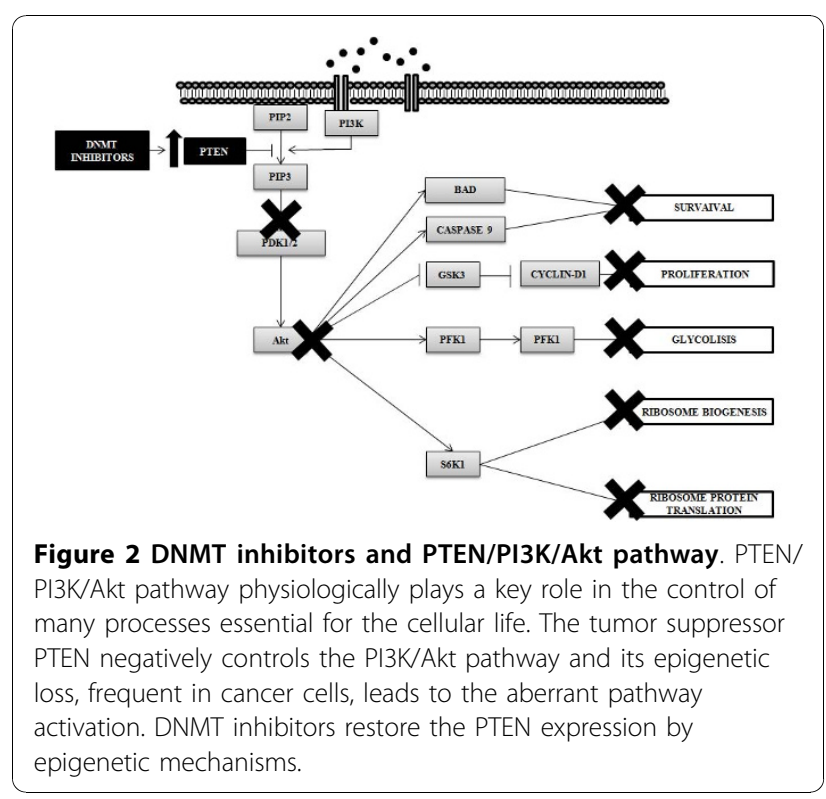


experimental model, suggests that the transfection of TC-32 Ewing sarcoma cells with Akt/PKB inhibits doxorubicin-induced apoptosis suggesting that PTEN increases doxorubicin cytotoxicity through the PI3K signaling pathway. Additional indication of chemosensitizing properties of PTEN derived from data obtained in endometrial cancer cells [41]. In this system, PTEN significantly enhanced chemosensitivity to doxorubicin. This effect was associated with the levels of phosphoAkt/PKB and phospho-Bad (Ser-136), which were reduced in the PTEN expressing clones. Results from other studies performed on brain tumors clearly show that decreasing activity of the PI3K/Akt pathway in tumor cells with mutant PTEN may contribute to the increased sensitivity to chemotherapy [42]. Down-regulating the Akt pathway by inducing PTEN also increases the sensitivity of glioblastoma cells to temozolomide.

\section{DNA base damage}

Some kind of acquired or intrinsic chemoresistance may be epigenetic in nature and operate at DNA mismatch repair level [43-48]. Interestingly, suppression of a DNA mismatch repair mechanism seems [49] to act in concert with other independent DNA mismatch repair machineries [50,51], resulting in drug resistance and genetic instability [52]. The suppression of DNA mismatch repair mechanism can occur at epigenetic level and in the absence of heritable inactivating mutations. Demethylating agents have been shown to reverse drug resistance to alkylating agents in some preclinical models of ovarian and colorectal cancer [53]. This process may happen through up-regulation of MLH1, and is mediated by 5 -Aza treatment, which sensitizes tumor cells to cisplatin. However, 5-Aza treatment does not sensitize MLH1 mutant cells to cisplatin, indicating that MLH1 gene reactivation is required for the sensitization [53,54]. If MLH1 reactivation is required for the sensitization to cisplatin, several concerns still exist about the value of epigenetic modulation of DNA repair genes in inducing chemosensitization. It is well known that MGMT, another DNA repair mediator, is frequently epigenetically silenced [55]. Consistent with its role in protecting the genome from $\mathrm{G}$ to A transitions, induced by alkylating agents, MGMT inactivation through its promoter hypermethylation has been associated with $\mathrm{G}$ to A mutations in $\mathrm{k}$-ras and p53 genes in colorectal cancer [56,57]. Even though DNMT inhibitors, such as 5-Aza and decitabine, have proven effective in re-expressing MGMT in cancer cells, the clinical advantage of the restored MGMT expression is doubtful [58-60] since tumors with the unmethylated promoter of MGMT gene appear significantly less susceptible to the cytotoxic effects of alkylating drugs $[56,57,60]$.

Although the biological effects of DNMT inhibitors on methylation and demethylation status of DNA mismatch repair genes have been extensively studied, DNA damage-related sequelae of these agents is still not fully understood. DNA Double Strand Breaks (DSBs) are the most cytotoxic DNA lesions. One-ended DSBs can be formed via collapse of a replication fork at the site of a blocking DNA lesion [61-64]. Given that DNMT inhibitors, as well as some chemotherapeutics, create irreversible covalent DNA-enzyme adducts, the convergence of these phenomena may be one possible mechanism by which these two agents synergize and induce cytotoxicity $[65,66]$. Several reports indicate that 5-Aza, decitabine and zebularine induce DSB responses followed by induced apoptosis. These responses may be mediated via ATR or ATM, which are two key mediators promoting DNA DSB response signalling [67-69]. Given that the DSB responses induced by 5-Aza and doxorubicin engage in distinct signaling pathways, the combination of these two agents may cooperate and synergistically induce cell death [70]. The induction of DNA damage response by Chk2 and p53 phosphorylation could be another mechanism by which DNMT inhibitors induce DNA damage-related sequelae and cooperate with chemotherapeutics [71-75]. In this regard, some studies revealed that decitabine may be cytotoxic against both p53 wild-type and p53 mutant containing tumor cells, suggesting that p53 function is not always required in order to mediate the apoptotic process of DNMT inhibitors. Finally, it has been demonstrated that these agents can induce DNA damage in a dose-dependent manner, while the degree and the kind of DNA damage induced parallels the amount of incorporated DNMT inhibitor [76]. This may be an important cooperative mechanism since when the cytotoxic effect of DNMT inhibitors takes place in close proximity of a single- or double-strand break induced by chemotherapeutics the damage may be lethal.

\section{Apoptosis}

Defects in apoptotic pathways promote chemoresistance. DNMT inhibitors are known to potentiate apoptotic processes through different pathways. Evidence suggests that the induction of TRAIL by decitabine is critical for sensitizing breast cancer cells to Adriamycin. The silencing of TRAIL decreases caspase activation and abrogates chemosensitization mediated by decitabine. Several mechanisms by which DNMT inhibitors induce TRAIL have been postulated. One of the possible mechanisms is the activation of TRAIL gene expression [77,78]. Additional evidence suggests that the induction of TRIAL by decitabine is mediated by the increase in the half-life of TRAIL protein [78] or by the induction of TRAIL via Akt. It is known that the PI3K inhibitor wortmannin can induce TRAIL [79], and that the overexpression of the active form of Akt can abolish TRAIL induction mediated by wortmannin. In agreement with 
this evidence, Akt, working as a negative modulator of TRAIL, is modulated by 5-Aza resulting in a decrease of phosphorylated Akt and enhanced TRAIL expression.

If TRAIL plays a key role in the apoptotic process mediated by DNMT inhibitors, other investigators suggest that the methylation in the promoter region of caspase 8 and caspase 9 is another well known mechanism by which tumors acquire chemoresistance. Mechanistic studies indicate that decitabine induces caspase- 8 and caspase- 9 and sensitizes tumor cells to TRAIL, etoposide, cisplatin $[80,81]$ and paclitaxel [82].

Overexpression of the Activator protein $2 \alpha(\mathrm{AP}-2 \alpha)$ is another mechanism through which DNMT inhibitors may induce apoptosis and influence chemosensitivity. $\mathrm{AP}-2 \alpha$ is a sequence-specific DNA-binding transcription factor that is required for regulation of many genes involved in many biological functions [83-85]. Growth inhibitory activity of AP- $2 \alpha$ is mediated through direct interaction with p53 [86] and the overexpression of this transcription factor induces cell cycle arrest and apoptosis $[87,88]$. Epigenetic targeting of AP- $2 \alpha$ inhibits tumor proliferation and increases tumor cell death [89]. This acquires a meaningful clinical significance considering that $75 \%$ of invasive breast tumors have epigenetically silenced AP-2 $\alpha$. Therefore, the use of DNMT inhibitors may provide the unique opportunity for modifying the chemosensitivity of breast cancer containing hypermethylated and silenced AP-2 $\alpha$ [90-95].

\section{Oxidative stress}

Agents inducing oxidative stress determine cellular damage by reactive oxygen intermediates (ROI). Small amounts of ROI may act as signalling molecules but if ROI production exceeds the endogenous intracellular antioxidative capacities $[96,97]$ an oxidative stress occurs [98] resulting in cell death. Increased ROI levels contribute to the development of chemoresistance and growing evidence supports a role of epigenetic processes in ROS-induced generation of oxidative stress [99-105]. The proto-oncogene AP-1 plays a central role in the control of cellular response to oxidative stress [106-109]. It modulates the expression of target genes involved in protective and/or reparative cellular responses to the damaging effects of oxidative stress [110-113]. Experimental data suggest that $\mathrm{H} 2 \mathrm{O} 2$ stress-resistant tumor cells have increased AP-1 DNA-binding activity and are resistant to the damaging effects of chemotherapeutic agents [114]. The inhibition of the AP-1 complex reverses the multimodality resistance phenotype (MMRP) in response to oxidative stress through the inhibition of Fos activity [114]. Other studies have expanded these observations showing that DNMT1, a downstream target of Fos, is upregulated in chemoresistant tumor cells [114]. These results indicate that the epigenome may play a critical role to oxidative stress and highlights a potential role of DNMT1 activity abrogation as a potential molecular target in chemoresistant tumor cells. This evidence has been further confirmed showing that the selective silencing of DNMT1 and DNMT3b greatly reduces the chemoresistance of tumor cells overexpressing DNMTs isoenzymes [115].

\section{DNMT inhibitors and radiotherapy}

The therapeutic index of radiotherapy can be improved by chemical agents that sensitize cancer cells to the toxic effects of ionizing radiation. Radiotherapy and systemic agents may interact through two main modalities (Figure 3). In the first modality, radiotherapy acts locoregionally and systemic agents act against micro-metastases without interaction between the treatments. In the second modality radiotherapy and systemic agents interact within the radiation field increasing tumor cell death.

Sparse biological data indicate that DNMT inhibitors may act as radiosensitizers. The meaningful advantage of DNMT inhibitors as radiosensitizers is that these agents can induce radiosensitization at concentrations several times lower than typical plasma levels obtained when used as single agents [116]. Major interactions between DNMT inhibitors and radiotherapy may be postulated. For clearer understanding, the potential biological mechanisms of cooperation between DNMT inhibitors and radiotherapy will be discussed separately. DNA repair

Radiation therapy induces DNA base damage, singlestrand breaks, and double-strand breaks (DSBs). These structural damages are repairable, except for DSBs, which are considered lethal [116]. 5-Aza, decitabine and zebularine lead to protein-DNA adducts and when the

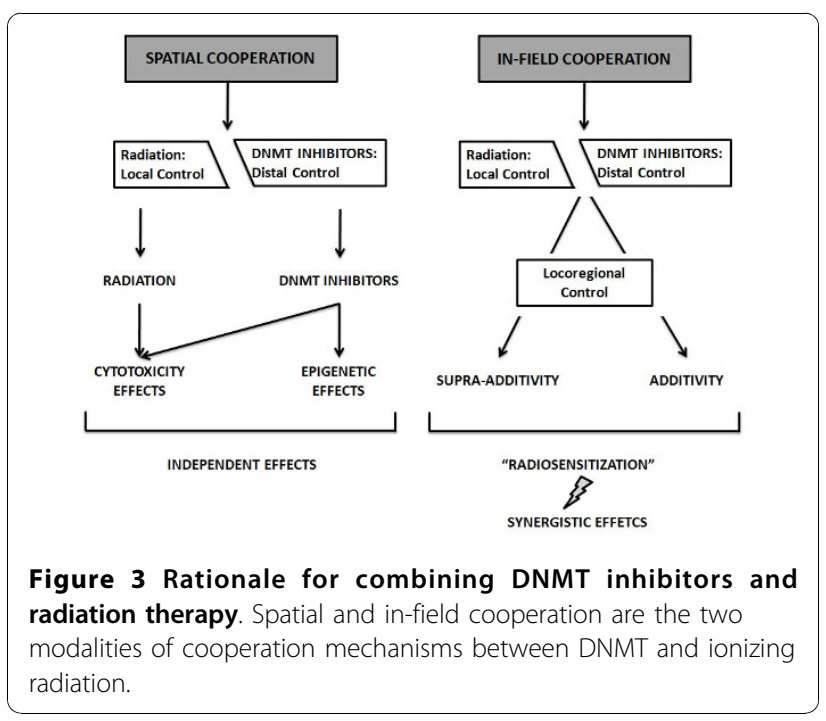




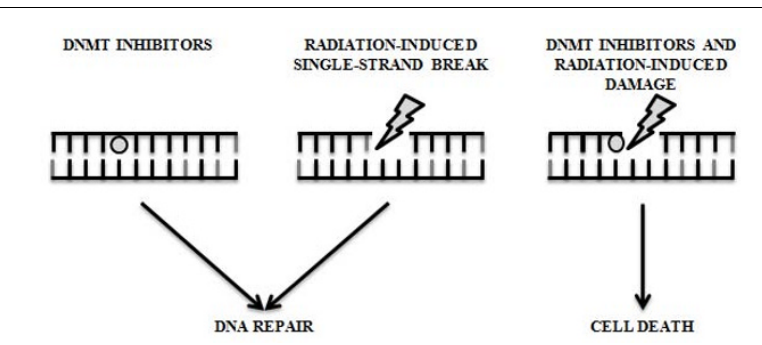

Figure 4 Cooperative cytotoxic mechanism between DNMT inhibitors and radiation. lonizing radiation induces DNA base damage, single-strand breaks, and double-strand breaks (DSBs). All of these errors can be rapidly repaired except for DSBs, which if not repaired are considered lethal. The cytotoxic effect of DNMT inhibitors in close proximity to a radiation-induced single-strand break can act synergistically to make the defect significantly more difficult to repair, consequently resulting in the induction of cellular death.

cytotoxic effect takes place in close proximity to a radiation-induced single-strand break, the damage may be significantly more difficult to repair (Figure 4 ). The DNA cytosine-C5 methyltransferase (MTase) acts on a cytosine residue through its recognition sequence by covalently binding to $\mathrm{C} 6$, and then transferring the methyl group from S-adenosylmethionine to C5. The covalent protein-DNA linkage is then reversed and the enzyme dissociates from the DNA. In this context, 5Aza, decitabine and zebularine substitution at the target cytosine interferes with the reaction cycle, which results in long-lived or irreversible MTase-DNA adducts [117-121]. The cytotoxic mechanism of DNMT inhibitors has been documented in in vivo models. Results from these studies suggest that (i) the formation of protein-DNA adducts mediate decitabine cytotoxicity [122], (ii) the cytotoxicity levels correlate positively with

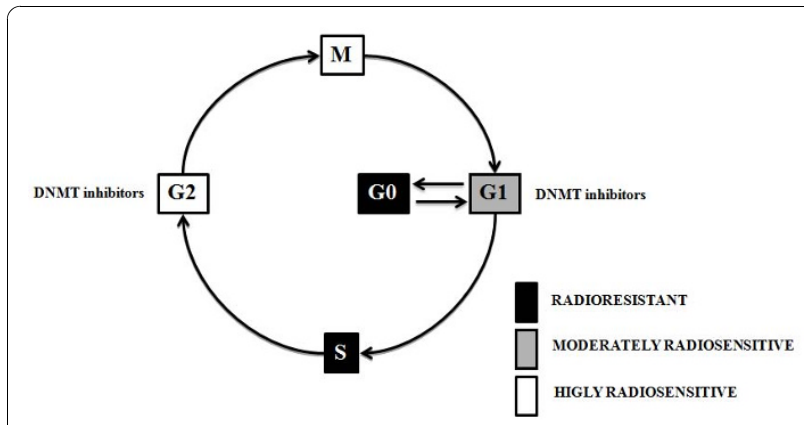

Figure 5 Cell cycle, DNMT inhibitors and radiosensitivity. The radiosensitivity of cells is dependent on the phase of the cell cycle. Cells in the $S$ phase are the most radio resistant, and cells in the G2-M phase of the cell cycle are the most radiosensitive. DNMT inhibitors synchronize with the cell cycle of tumor cells increasing the efficacy of subsequent radiotherapy.
MTase levels [123], and (iii) decitabine induce p53 DNA damage response by MTase-DNA adducts [124-127]. Cell cycle

The radiosensitivity of tumor cells is dependent on the phase of the cell cycle. Cells in the S-phase are the most radioresistant, whereas cells in the G2-M phase are the most radiosensitive. Evidence indicates that DNMT inhibitors synchronize tumor cells preferentially in the G1 or $\mathrm{G} 2 / \mathrm{M}$ phase of the cell cycle increasing the efficacy of radiotherapy (Figure 5). In this way, if administered concurrently to radiotherapy, the inhibitors may cooperate to produce additive or synergistic antitumor effects. Qui and co-workers demonstrated that low concentrations of decitabine synchronize gastric tumor cells in the G2/M phase of the cell cycle and induce radiosensitization [116]. The radiosensitizing effect of this inhibitor seems to be partly mediated by $p 53, R A S S F 1$, and DAPK [116]. RASSF1 and DAPK modulate multiple apoptotic and cell-cycle checkpoint pathways [128,129] and the loss of RASSF1 and DAPK expression is documented in a wide range of human tumors as a result of silencing, primarily from promoter hypermethylation [130]. Therefore, the epigenetic modulation of RASSF1 and $D A P K$ shines some light on the synergism between DNMT inhibitors and radiotherapy in terms of apoptotic signaling modulation.

\section{Angiogenesis}

Induction of anti-angiogenic activity in radiotherapy as a result of combined treatments with DNMT inhibitors is backed by a clear rationale. Common in many cancers hypoxia has been indicated as a marker of aggressive clinical behaviour, poor prognosis and unsatisfying radiation response. Therefore, any compound able to increase perfusion and oxygenation reduces the radioresistant hypoxic areas counteracting the onset of hypoxic and radioresistant clones.

Experimental data suggest that many key modulators of angiogenesis are under epigenetic control. The promoter of von Hippel-Lindau (VHL) tumor suppressor gene is hypermethylated and its absence leads to a failure in degradation of hypoxia inducible factor (HIF)-1 whose accumulation favors tumor angiogenesis [131]. This aberrant pathway has been successfully inactivated by decitabine, which in addition to restoring VHL expression, down-regulates the vascular endothelial growth factor (VEGF), the glucose transporter (GLUT)-1 [132] and the thrombospondin-1 [133]. Radiotherapy has been shown to kill proliferating endothelial cells. Therefore, any drug that acts on endothelial cells induces a significant increase in the cytotoxic effect of radiotherapy decreasing the levels of angiogenesis. DNMT inhibitors act directly on activated endothelial cells and inhibit angiogenesis in vitro and in vivo [132]. Decitabine and its analogue zebularine exhibit significant angiostatic activity. This is 
accompanied by a significant effect on the expression levels of angiogenesis inhibiting genes (TSP1, JUNB, and IGFBP3). TSP1 is known to block endothelial cell migration and to induce apoptosis. JUNB negatively regulates cell growth by activating p16INK4A and decreasing cyclin D1 expression [132], while IGFBP3, a key regulator of cell growth and apoptosis, inhibits VEGF-mediated HUVEC proliferation [133] and angiogenesis [133]. Reexpression of these growth-inhibiting genes by DNMT inhibitors, in activated endothelial cells, may contribute to a decrease in angiogenesis and improvement in intrinsic radiosensitivity.

\section{Apoptosis}

Apoptosis is a well known mechanism through which antitumor agents induce radiosensitization. DNMT inhibitors sensitize tumor cells to apoptosis either by restoring the defective expression of apoptotic effector proteins, or by re-establishing the expression of signal transducing/mediators of the apoptotic signals. 5-Aza restores the expression of DAPK1 in bladder carcinoma and B-cell lines [134] and the re-expression of DAPK1 in Burkitt's lymphoma cell lines restores the susceptibility to IFN- $\alpha$ triggered apoptosis [135]. Similarly, DNMT inhibitors sensitize NSCLC cells to TRAIL-induced apoptosis by inducing DAPK1 expression [136]. Besides DAPK1, 5-Aza and DNMT1 antisense oligonucleotides are able to restore the sensitivity of cancer cells to IFNtriggered apoptosis despite the re-expression of the proapoptotic gene RASSF1A and XAF1 which are frequently silenced by epigenetic mechanisms [137,138]. Caspases are not spared from epigenetic inactivation during tumor transformation. Hypermethylation of caspase- 8 promoter leads to its either reduced expression or complete absence in neoplastic cells resulting in their resistance to death receptor and drug-induced apoptosis. However, 5-Aza has proven to be effective in re-establishing caspase- 8 expression in cancer cells, restoring their sensitivity to TRAIL-, anti-FAS-, and drug-triggered apoptosis [35,139-141].

\section{Cell signaling}

DNMT inhibitors are modulators of gene expression and may increase the expression levels of many key genes, specifically the ones involved in the radiosensitizing processes. NF- $\kappa \mathrm{B}$ is capable of activating a number of genes involved in stress response, inflammation, and apoptosis. Loss or inhibition of NF- $\kappa \mathrm{B}$ activation leads to radio-sensitization [142-144]. The elevated basal NF$\kappa \mathrm{B}$ activity in certain cancers has been linked with tumor resistance to chemotherapy and radiation [145]. Together with the assumption that NF- $\kappa \mathrm{B}$ is capable of regulating more than 150 effector genes, this transcription factor plays a key role in tumor radioadaptive resistance under fractional ionizing radiation. 5-Aza can rapidly induce inhibition of NF-kB [146]. This effect may be achieved via down-regulation of pro-survival and anti-apoptotic (IL-6, IL-6Ra, Bcl-XL) mediators or abrogating drug-induced NF-kB stress responses $[147,148]$. PARP-1 represents the essential transcriptional co-regulator implicated in radiation-induced NF$\kappa \mathrm{B}$, AP-1, Oct1, and HIF- $1 \alpha$ activation [149]. Experimental results demonstrate that the ATM gene is a target for silencing through aberrant methylation of its proximal promoter region $[150,151]$. This epigenetic event can result in a decreased expression of ATM, resulting in a radioresistant phenotype consistent with reduced ATM function. DNMT inhibitors, positively affecting the levels of ATM, increase radiosensitivity in human colorectal tumor cell lines. In this regard, the moderate radiosensitivity displayed by HCT-116 cells can be increased by 5 -azacitidine treatment, correlating with ATM levels [151].

\section{Epigenetic control of oncogenes: implication for standard treatments}

Global genomic hypomethylation has been documented in most solid tumors [152-154]. Evidence suggests that this post-translational mechanism supports tumor development [155]. In solid human tumors, a correlation between global genomic hypomethylation and advanced tumor stage has been established [154].

Methylation has been primarily considered as a mechanism for tumor suppressor genes silencing and genome profiling approaches have identified several putative tumor suppressor genes silenced by promoter hypermethylation. So far, unmasked expression of putative oncogenes has been sporadically reported [156].

Although c-myc was among the very earliest oncogenes identified and the subject of intense study, it has nonetheless proven to be an enduring enigma. Results to date suggest that Myc-Max influences cell growth and proliferation through direct activation of genes involved in DNA synthesis, RNA metabolism and cellcycle progression [157]. Early studies showed that c-myc is under epigenetic control and its functional silencing sensitizes cancer cells to chemotherapy and radiotherapy [158-160]. These sensitizing effects of c-Myc were primarily achieved by inhibiting MLH1 and MSH2 mismatch repair proteins [161]. Evidence suggests that decitabine is unable to modify the expression of c-myc in gastric cancer [161]. Other evidence, however, suggest that several proto-oncogenes, whose promoters are under epigenetic control, may be down-regulated rather than up-regulated after treatment with epi-drugs [162]. Microarray data revealed that the treatment of myeloma multiple cells by decitabine and TSA resulted in downregulation of several proto-oncogenes such as members of myc family [162]. Of note, the down-regulation of these genes was more a response to TSA and 
decitabine/TSA than to decitabine alone. The biological rationale for this surprising phenomenon is not well known although this effect may be explained either by a direct inhibitory action of decitabine and TSA or by an indirect down-regulation by decitabine and TSA affected genes [162].

Therefore, these conflicting data may have important therapeutic implications since demethylation-based therapy can cause unintended effects. It may be possible that in certain tissues and under selective biological conditions epi-drugs may result in either up- or down-regulation of proto-oncogenes [163]. These concerns may explain either some of the side effects or the unsuccessful results documented upon demethylation-based therapy in solid tumors.

\section{Response of normal tissues to DNMT inhibitors}

The use of DNMT inhibitors raises questions regarding their potential to epigenetically affect non-cancerous cells. Therefore, an important issue is a need for a more complete understanding of the potential benefits and limitation of DNA methylation as a human cancer drug target. Conflicting evidence exist in literature regarding the effect of DNMT inhibitors on normal cells. Even though well known toxicity profile has been documented for DNMT inhibitors, especially for nucleoside analogues such as 5-Aza and decitabine in the clinical setting (Table 2), many doubts exist about their long-term safety as well as about their mutagenic and carcinogenic potential [164]. Some evidence indicate that intraperitoneal injection of 5-Aza at doses ranging from 2.0 to $2.2 \mathrm{mg} / \mathrm{kg}$ for $50-52$ weeks in murine models increased the incidence of malignant tumors of hematopoietic and lymphoreticular system as well as of lung, mammary glands and skin [165]. The mutagenic potential of 5-Aza [165] and decitabine [166] was tested in vitro and in vivo systems. Both analogues increased mutation frequency in L5178Y mouse lymphoma cells, and mutations were produced in an Escherichia coli lac-I transgene in colonic DNA of decitabine-treated mice [166]. Decitabine, moreover, resulted in chromosomal rearrangements in larvae of fruit flies. The effect of decitabine and 5-Aza on postnatal development and reproductive capacity was evaluated in murine models. Administration of these inhibitors in male mice resulted in decreased fertility and loss of offspring during subsequent embryonic and postnatal development. Decreased weight of the testes and epididymides with reduced sperm counts were also detected. Body weights of males and females exposed in utero to decitabine were significantly reduced at all postnatal time points. No consistent effect on fertility was seen when female mice exposed in utero.
However, if the aforementioned data indicate that both 5-Aza and decitabine have a tangible toxicity on normal tissues, recent biological data seem to suggest that normal cells may interact differently with DNMT inhibitors than malignant cells. In this regard, some data suggest that normal cells, dividing at a slower rate than malignant cells, incorporate less drug than cancer cells into their DNA resulting in decreased effect on DNA methylation. Zebularine, a novel DNA methyltransferase inhibitor, has properties of acting differentially on cancerous and normal cells. Continuous treatment with this drug substantially reduces the growth rate of human cancer cells with less effect on normal human fibroblasts. Growth inhibition in cancer cells was found to be associated with the induction of $p 21$ which was unmodified in human fibroblasts. This suggests that the growthsuppressive potential of zebularine in tumor cells is seemingly $p 21$-dependent and its differential effects was partially due to preferential incorporation of zebularine into DNA of tumor cells as documented by the uridine/ cytidine kinase activity levels that were generally higher in cancerous than normal cells. Therefore, the preferential effects of zebularine in cancer cells in terms of incorporation into DNA, growth inhibition, demethylation, and depletion of DNMTs are probably due to differential metabolism compared to normal cells.

If different metabolism between normal and malignant cells may partially explain the preferential effect of DNMT inhibitors on tumor cells [167], the differential genes expression that these inhibitors induce in different cellular sub-populations is equally relevant. Karpf and coworker conducted a genomic analysis of gene expression modifications upon decitabine treatment both in normal and cancerous cell lines. In their analysis the authors concluded that decitabine (i) elicited changes in a limited number of genes, (ii) regulated gene expression similarly between normal and cancer cells, and (iii) changes in the expression of specific genes required the presence of transcriptional activators competent for activation of the target promoter $[168,169]$. However, if the differences in gene expression patterns between normal and malignant cells upon DNMT inhibitors seem to be less marked than previously seen, the selective activation of specific genes in tumor cells is clearly documented in literature. In this regard, decitabine leads to the selective activation of specific genes only in tumor cells opening to the intriguing hypothesis that DNMT inhibitors may increase the therapeutic index of specific antitumor strategies consenting of targeting the gene products differentially expressed in tumor cells [169].

Xerostomia is a common complication of radiotherapy on head and neck cancer due to irreparable damage caused to the salivary glands if they are included in the radiation fields. This side effect is perceived negatively 


\begin{tabular}{|c|c|c|}
\hline & 5-Azacitidine & Decitabine \\
\hline General & $\begin{array}{l}\text { Pyrexia, fatigue, weakness, rigors, pain in limb, back pain, } \\
\text { contusion, dizziness, erythema, chest pain, epistaxis, myalgia, } \\
\text { decreased weight, abdominal pain, aggravated fatigue, } \\
\text { abdominal tenderness, insomnia, malaise, pain, upper abdominal } \\
\text { pain, night sweats, lethargy, peripheral swelling, transfusion } \\
\text { reaction, abdominal distension, syncope, chest wall pain, } \\
\text { hypoesthesia, post procedural pain, general physical health } \\
\text { deterioration, systemic inflammatory response. }\end{array}$ & $\begin{array}{l}\text { Pyrexia, peripheral edema, rigors, edema, pain, lethargy, } \\
\text { tenderness, fall, chest discomfort, intermittent pyrexia, malaise, } \\
\text { crepitations. }\end{array}$ \\
\hline Local & $\begin{array}{l}\text { Injection site erythema, injection site pain, injection site bruising, } \\
\text { injection site reaction, injection site pruritus, injection site } \\
\text { granuloma, injection site pigmentation changes, injection site } \\
\text { swelling. }\end{array}$ & Erythema, catheter site pain, and injection site swelling. \\
\hline Cardiovascular & & Cardiac murmur, hypotension, pulmonary edema. \\
\hline Respiratory & $\begin{array}{l}\text { cough, dyspnea, nasopharyngitis, exertional dyspnea, productive } \\
\text { cough, pneumonia, lung crackles, rhinorrhea, rales, wheezing, } \\
\text { decreased breath sounds, pleural effusion, postnasal drip, } \\
\text { rhonchi, nasal congestion, atelectasis, exacerbated dyspnea, } \\
\text { sinusitis, hemoptysis, lung infiltration, pneumonitis, respiratory } \\
\text { distress }\end{array}$ & $\begin{array}{l}\text { cough, pharyngitis, lung crackles, decreased breath sounds, } \\
\text { hypoxia, rales, postnasal drip. }\end{array}$ \\
\hline Musculoskeletal & $\begin{array}{l}\text { arthralgia, muscle cramps, aggravated bone pain, muscle } \\
\text { weakness, and neck pain. }\end{array}$ & $\begin{array}{l}\text { arthralgia, limb pain, back pain, chest wall pain, musculoskeletal } \\
\text { discomfort, myalgia }\end{array}$ \\
\hline Hematologic & $\begin{array}{l}\text { anemia, thrombocytopenia, leukopenia, neutropenia, febrile } \\
\text { neutropenia, hypokalemia, post procedural hemorrhage, } \\
\text { aggravated anemia, agranulocytosis, bone marrow depression, } \\
\text { bone marrow failure, pancytopenia, and splenomegaly. }\end{array}$ & $\begin{array}{l}\text { neutropenia, thrombocytopenia, anemia, febrile neutropenia, } \\
\text { leukopenia, lymphadenopathy, and thrombocythemia. }\end{array}$ \\
\hline Gastrointestinal & $\begin{array}{l}\text { nausea, vomiting, diarrhea, constipation, anorexia, pharyngitis, } \\
\text { appetite decreased, gengival bleeding, oral mucosal petechiae, } \\
\text { stomatitis, dyspepsia, hemorrhoids, loose stools, dysphagia, } \\
\text { mouth hemorrhage, tongue ulceration, diverticulitis, } \\
\text { gastrointestinal hemorrhage, melena, perirectal abscess }\end{array}$ & $\begin{array}{l}\text { nausea, constipation, diarrhea, vomiting, abdominal pain, oral } \\
\text { mucosal petechiae, stomatitis, dyspepsia, ascites, gingival } \\
\text { bleeding, hemorrhoids, loose stools, tongue ulceration, } \\
\text { dysphagia, oral soft tissue disorder, lip ulceration, abdominal } \\
\text { distension, abdominal pain upper, gastroesophageal reflux } \\
\text { disease, glossodynia. }\end{array}$ \\
\hline Dermatologic & $\begin{array}{l}\text { ecchymosis, petechiae, skin lesions, rash, pruritus, increased } \\
\text { sweating, urticaria, dry skin, skin nodule, pyoderma } \\
\text { gangrenosum, pruritic rash, and skin induration. }\end{array}$ & $\begin{array}{l}\text { ecchymosis, rash, erythema, skin lesion, pruritus, alopecia, } \\
\text { urticaria, and facial swelling. }\end{array}$ \\
\hline Immunologic & & $\begin{array}{l}\text { Infections and infestations such as pneumonia, cellulitis, candidal } \\
\text { infection, catheter related infection, urinary tract infection, } \\
\text { staphylococcal infection, oral candidiasis, sinusitis, bacteremia. }\end{array}$ \\
\hline $\begin{array}{l}\text { Nervous } \\
\text { System }\end{array}$ & headache, convulsions, intracranial hemorrhage. & $\begin{array}{l}\text { headache, dizziness, hypoesthesia, insomnia, confusional state, } \\
\text { anxiety. }\end{array}$ \\
\hline Others & $\begin{array}{l}\text { pallor, pitting edema, lymphadenopathy, hematoma, cellulitis, } \\
\text { infections and infestations including herpes simplex, limb } \\
\text { abscess, bacterial infection, blastomycosis, injection site infection, } \\
\text { Klebsiella sepsis, streptococcal pharyngitis, Klebsiella pneumonia, } \\
\text { sepsis, Staphylococcal bacteremia, Staphylococcal infection, } \\
\text { neutropenic sepsis, septic shock, toxoplasmosis, genitourinary } \\
\text { infection, hematuria. }\end{array}$ & $\begin{array}{l}\text { vascular disorders such as petechiae, pallor, hematoma, } \\
\text { increased blood alkaline phosphatase, aspartate } \\
\text { aminotransferase, blood urea, blood lactate dehydrogenase, } \\
\text { blood bicarbonate, decreased blood albumin, blood chloride, } \\
\text { protein total, blood bicarbonate, blood bilirubin, hyperglycemia, } \\
\text { hypoalbuminemia, hypomagnesemia, hypokalemia, } \\
\text { hyponatremia, decreased appetite, anorexia, hyperkalemia, } \\
\text { dehydration, hyperbilirubinemia, transfusion reactions, blurred } \\
\text { vision, dysuria, urinary frequency. }\end{array}$ \\
\hline
\end{tabular}

by many patients with a significant impact on their quality of life. This condition is partially due to the death of a significant number of glandular ductal cells, which if not replaced, result in a significant decrease in the amount of produced saliva. Motegi and coworkers examined the mechanism by which immortalized normal human salivary gland ductal cells acquire the ability to express Aquaporin 5 (AQP5) and secrete fluid in response to decitabine treatment [170]. AQP5 is a water channel protein and its role in the generation of saliva, tears and pulmonary secretion is well documented. These authors suggest that decitabine resulted in AQP5 gene expression in human salivary gland ductal cells (NS-SV-DC cells) affecting the water permeability by increasing the transepithelial net fluid secretion of surviving ductal cells. However, the improvement in the efficiency of transepithelial fluid secretion may be of limited value if the noxa patogena holds over the response of normal tissue is the production of fibrosis that results in to the complete loss of tissue function. 
Therefore, drugs capable of reducing the fibrinogenic potential of specific treatments are of value in clinical setting.

Some authors documented that DNA methylation exert epigenetic control over fribrinogenesis and wound healing. These events need a process of cell transdifferentiation of resident cells to stellate cells, a particular subtype of myofibroblast, which seems to be a common process in the majority of soft tissues. Myofibroblasts are highly profibrinogenic and produce proinflammatory mediators (IL-6, MCP-1, PFGF, TGF $\beta-1$ ) resulting in the secretion of a large quantities of collagen I and III [171]. MeCP2 is a methyl-CpG-binding protein that has the potential to exert regulation over the expression of multiple genes via its interaction with methylated DNA. $\mathrm{MeCP} 2$ is a repressor of $\mathrm{IkB} \alpha$ which is required for transdifferentiation and profibrinogenic activity of stellate cells. Another important mediator of transdifferentiation and fribrinogenesis is PPAR $\gamma$ whose transcriptional silencing activity is required for conversion of hepatic stellate cells to myofibroblast [172]. Forced expression of PPAR $\gamma$ in hepatic myofibroblast results in reversing the transdifferentiation and profibrinogenic potential of stellate cells with down-regulation of type I collagen, loss of proliferation, and reacquisition of their adipogenic characteristics. Experimental data suggest that $\mathrm{MeCP} 2$ is recruited to the $\mathrm{IkB} \alpha$ promoter and decitabine treatment modulating epigenetically the expression these mediator exerts control over key fibrinogenic and inflammatory transcriptional regulators reducing greatly the fibrogenic potential of stellate cells [173].

Another significant property of DNMT inhibitors is their capability to act as antioxidants under specific biological setting. This property is very important, especially in conditions where an excess of free radicals results in tissue damage. EGCG is a major element of green tea with a documented activity as DNMT inhibitor. Conflicting data are available in literature on the effect of EGCG on normal and tumoral cells. In an immortalized normal breast epithelial cell line (MCF10A), EGCG induced growth arrest prior to the cell cycle restriction point, with elevated $\mathrm{p} 21$, hypophosphorylation of $\mathrm{Rb}$, and decreased cyclin $\mathrm{D} 1$, suggesting that higher concentrations of EGCG may be toxic to normal mammary epithelial cells [174]. However, EGCG may have both antioxidant and prooxidative activities involved in redox cycling and quinone formation [175] and may induce oxidative stress in vivo $[176,177]$. Cysteine conjugates, indicative of reactive species development, have been detected after 200 and $400 \mathrm{mg} / \mathrm{kg}$ i. p. EGCG [178]. EGCG was also reported to be capable of inducing liver, kidney and gastrointestinal toxicity which seemed to be correlated with bioavailability of
EGCG $[176,179]$. Different results were documented by Yamamoto and his group [180] since new mechanisms by which EGCG may act differentially in tumor and normal cells were identified. In humans, EGCG is rapidly absorbed through the oral mucosa and secreted back into the oral cavity by saliva, suggesting that salivary glandular cells may tolerate high concentrations of EGCG [181]. Accordingly, this evidence suggests that EGCG may differentially affect oxidative status and may act as either a ROS inducer or a ROS suppressor depending upon the cell type [182]. EGCG concentrations higher than plasma Cmax do not produce ROS in cells derived from the normal epidermis and oral cavity but rather protect these cells by decreasing ROS production. Mechanisms responsible for the differential effects could rely on distinctive signal pathways activated by EGCG in a tissue-specific manner. High concentration of EGCG failed to produce ROS in normal epidermal keratinocytes, and immortalized normal salivary gland cells. In contrast, EGCG elevated ROS levels upon treatment in a dose-dependent manner in oral carcinoma cells. The ROS levels were significantly higher in the tumor cell lines that possessed low catalase activity. Therefore, EGCG may potentially simultaneously enhance tumor cell death rate and protect normal cells from chemo/radiation-induced oxidative stress in tumors such as skin and head neck [182].

If uncertainty exists regarding the effect of DNMT inhibitors on normal tissues, scanty direct evidence exists regarding the biological effects these inhibitors have in combination with chemotherapy or ionizing radiation. Clinical data indicate that, when decitabine is administered in association with cisplatin in subjects with advanced squamous cell carcinoma of the cervix, a significant hematological toxicity is documented [183].

Recent study reported interesting evidence of biological interaction of a DNMT inhibitor with chemotherapy. In this report 5-Aza was combined with cisplatin in order to measure the improvement in the therapeutic index of these two drugs. Interestingly, 5-Aza prevented the nephrotoxicity related to cisplatin, which was further related with the lowering in the levels of BUN and creatinine in the murine model. The mechanism by which 5-Aza decreased the nephrotoxicity involved the reduction of the levels of mediators such as metallothioneins, which are able to induce oxidative stress or indirectly activate gene responsible for preventing oxidative stress. This represents the first evidence that an epigenetic treatment with a DNMT inhibitor reduces the toxicity related to chemotherapy [184]. A single study dealing with the combination of decitabine with ionizing radiation reports in a differentiated effect in terms of growth inhibition normal and cancerous cells [185]. When decitabine was combined with radiation no significant 
synergism in terms of growth inhibition was found on human fibroblasts. On contrary, irradiation alone resulted in a significant decrease in the proliferation of normal fibroblasts, suggesting that decitabine significantly modified cellular response to irradiation.

\section{Off-target effects of DNMT inhibitors and potential contribution to radiosensitization}

The mechanisms by which DNMT inhibitors exert their effects on cells may be divided into those related to DNMT inhibitors and those not related to demethylation of DNA. The latter mechanisms may be defined as off-target effects and although observed at higher concentrations may substantially contribute to the antitumor properties of nucleoside analogues alone or in combination with chemotherapy or ionizing radiation. Numerous chemicals as well as radiation can lead to covalent protein-DNA adducts. 5-Aza, one of the most important nucleoside analogue, leads to protein-DNA adducts. 5-Aza is a cytidine analogue in which carbon-5 (C5) of the pyrimidine ring is replaced with nitrogen. Normally, a DNA cytosine-C5 methyltransferase (MTase) acts on cytosine residue in its recognition sequence by covalent binding to $\mathrm{C6}$, and then transferring the methyl group from $\mathrm{S}$-adenosylmethionine to C5; the covalent protein-DNA adduct is then reversed and the enzyme dissociates from the DNA [186]. 5-Aza substitution at target cytosine interferes with the reaction cycle and results in long-lived or irreversible MTase-DNA adduct. A major consequence of 5-Aza treatment is loss of cytosine MTase activity [186]. In mammalian cells, 5-Aza results in defective tRNA and rRNAs and inhibits protein synthesis [187]. Additionally, decitabine results in the induction of p53 DNA damage response, proposed to be dependent on formation of MTase adducts [188]. Covalent protein-DNA adducts or tightly bound proteins represent a major challenge to the DNA replication machinery. DNA replication forks can be blocked in vivo by replication termination complexes [189]. As previously described, scanty evidences indicate that nucleoside analogues may be efficient radiosensitizers. The cytotoxic mechanisms of nucleoside analogues may potentiate the effects of ionizing radiation for several theoretical reasons. First, as DNA synthesis inhibitors, nucleoside analogues have a potential to inhibit the repair of genomic damage induced by ionizing radiation. Second, because they are preferentially cytotoxic to proliferative cells, these analogues may decrease the number of tumor clonogens and thus slow down cell repopulation during fractionated radiotherapy. Tumor shrinkage induced by these compounds may improve tumor oxygenation and counter the detrimental effect of tumor hypoxia on radiation response. Third, a nucleoside analogue with DNA chain terminator property may, following their incorporation into the DNA repair patch, trigger an apoptotic response similar to that observed during the replication phase. Since DNA damage is induced in all phase of the cell cycle by radiation, this mechanism offers the prospect of extending the cytotoxicity of these analogues to non-S-phase cells. Due to the very low number of studies facing this topic the aforementioned mechanisms are all putative and specific experimental studies in vitro and in vivo settings should be performed in order to confirm these hypotheses.

\section{Combination of DNMT inhibitors with HDAC inhibitors}

Due to their relative antitumor selectivity DNMT inhibitors have been used in combination with HDAC inhibitors. Recently, there have been several excellent reviews of the histone deacetylase inhibitors (HDACIs) field used as a therapeutic option alone or in association with a variety of novel and conventional anticancer agents [190-192]. Optimal re-expression of methylated genes such as tumor suppressor or other cancer relevant genes following the serial application of a DNA methyltransferase inhibitor followed by an HDAC inhibitor created significant interest in combination epigenetic therapy. Among these p16INK4A and p14INK4b, Apaf-1 and caspase- 8 are efficiently re-expressed when DNMT inhibitors and HDACIs are combined [190-192]. DNMT and a group of methyl-cytosine binding proteins, e.g., $\mathrm{MeCP} 2$, can also recruit and direct HDACs to the chromatin associated with silenced genes. Combined treatment with a DNMT inhibitor and HDACI has been shown to be superior in de-repressing silenced tumor suppressor genes, as well as in inducing increased growth inhibition, differentiation and apoptosis of cancerous cells. The best results in de-repressing silenced genes are observed when DNMT inhibitors are used first at relatively low doses followed by exposure to the HDACIs.

\section{Conclusions and Future Directions}

No doubt exists that combining traditional cancer therapy with epigenetic modulators and reversing the changes of DNA methylation pattern holds a huge potential for successful treatment of haematological and solid malignancies. There are a number of important steps that need to be accomplished on the path towards efficient epigenetic therapy. Firstly, it is important to gain more insight into the diverse molecular mechanisms of the epi-drugs available today. A body of experimental evidences suggests that DNMT inhibitors may serve as efficient chemo- and radiosensitizers in solid tumors. However, the observation reported need more support in order to indicate intimate molecular mechanisms of chemo- and radiosensitization. Additionally, the 
understanding of different mechanisms as well as the long term safety of DNMT inhibitors on normal cells alone or in combination with standard treatments remains very limited and requires further research efforts. Although clinical and preclinical data indicate a substantial toxicity of these inhibitors, other evidence seems to suggest that these drugs may have potential in reducing toxicity under specific conditions. Therefore, the future goal is to indentify compounds able to enhance the therapeutic index and protect the non malignant tissues from side effects. Finally, other preclinical data suggest that the sensitizing effects of DNMT inhibitors seem to depend on the epigenetic modulation of a wide array of genes. A non negligible part of this effect may be related to the off-target mechanisms. Future research will focus on establishing clinically relevant combinations of DNMT inhibitors and conventional cancer therapies. In particular, a longstanding interest exists in the development of molecules that can modify cellular responses to radiation and chemotherapy. The future perspectives lie in identifying more similar compounds and elucidating their mechanisms of action in order to develop more effective cancer therapies and treatments.

\section{Acknowledgements}

The authors wish to express the gratitude to Dr. Mario Di Staso (Division of Radiotherapy, San Salvatore Hospital, L'Aquila), Dr. Pierluigi Bonfili (Division of Radiotherapy, San Salvatore Hospital, L'Aquila), and Dr. Mario Tombolini (Department of Otorhinolaryngology, Audiology and Phoniatrics 'G. Ferreri', University 'La Sapienza', Rome, Italy) for critical review and helpful discussion with the manuscript.

\section{Author details \\ ${ }^{1}$ Department of Experimental Medicine, Division of Radiation Oncology, S. Salvatore Hospital, L'Aquila, University of L'Aquila, Medical School, L'Aquila 67100, Italy. ${ }^{2}$ Department of Experimental Medicine, Laboratory of Radiobiology, University of L'Aquila, Medical School, L'Aquila 67100, Italy. ${ }^{3}$ Department of Cancer Biology and Medical Oncology, Kimmel Cancer Center, Thomas Jefferson University, Philadelphia, PA 19107, USA.}

\section{Authors' contributions}

GLG, CF, FM, RGP and VT drafted and wrote the manuscript. VP and BMZ revised the manuscript critically for important and intellectual content. GLG and FM supervised the project. All authors read and approved the final manuscript.

\section{Competing interests}

The authors declare that they have no competing interests.

Received: 18 February 2010 Accepted: 25 November 2010 Published: 25 November 2010

\section{References}

1. Horn PJ, Peterson CL: Heterochromatin assembly: A new twist on an old model. Chromosome Res 2006, 14:83-94.

2. Luger K: Structure and dynamic behavior of nucleosomes. Curr Opin Genet Dev 2003, 13:127-135.

3. Saha A, Wittmeyer J, Cairns BR: Chromatin remodelling: The industrial revolution of DNA around histones. Nat Rev Mol Cell Biol 2006, 7:437-47.
4. Marks PA, Rifkind RA, Richon VM, Breslow R: Inhibitors of histone deacetylase are potentially effective anticancer agents. Clin Cancer Res 2001, 7:759-60.

5. lizuka M, Smith MM: Functional consequences of histone modifications. Curr Opin Genet Dev 2003, 13:154-60.

6. Spotswood HT, Turner BM: An increasingly complex code. J Clin Invest 2002, 110:577-82.

7. Bird A: DNA methylation patterns and epigenetic memory. Genes Dev 2002, 16:6-21.

8. Jones PA, Baylin SB: The fundamental role of epigenetic events in cancer. Nat Rev Genet 2002, 3:415-428.

9. Bestor TH: The DNA methyltransferases of mammals. Hum Mol Genet 2000, 9:2395-2402.

10. Okano M: DNA methyltransferases Dnmt3a and Dnmt3b are essential for de novo methylation and mammalian development. Cell 1999, 99:247-257.

11. Okano M: Cloning and characterization of a family of novel mammalian DNA (cytosine-5) methyltransferases. Nat Genet 1998, 19:219-220.

12. Rhee I: DNMT1 and DNMT3b cooperate to silence genes in human cancer cells. Nature 2002, 416:552-556.

13. Rhee I: CpG methylation is maintained in human cancer cells lacking DNMT1. Nature 2000, 404:1003-1007.

14. Gravina GL, Festuccia C, Millimaggi D, Dolo V, Tombolini V, De Vito M: Chronic Azacitidine Treatment Results in Differentiating Effects, Sensitizes Against Bicalutamide in Androgen-Independent Prostate Cancer Cells. The Prostate 2008, 68:793-801.

15. Herman JG, Baylin SB: Gene silencing in cancer in association with promoterhypermethylation. N Engl J Med 2003, 349:2042-2054.

16. Silverman $L R$, Demakos EP, Peterson BL: Randomized controlled trial of azacitidine in patients with the myelodysplastic syndrome: a study of the cancer and leukemia group B. J Clin Oncol 2002, 20:2429-40.

17. Cameron EE, Bachman KE, Myohanen S, Herman JG, Baylin SB: Synergy of demethylation and histone deacetylase inhibition in the re-expression of genes silenced in cancer. Nat Genet 1999, 21:103-7.

18. kristensen LS, Nielsen HM, Hansen LL: Epigenetic and cancer treatment. European Juornal of Pharmacology 2009, 625:131-142.

19. Oki Y, Aoki E, Issa JP: Decitabine-Bedside to bench. Crit Rev Oncol 2007, 61:140-152

20. Larsen AK, Escargueil AE, Skladanowski A: Resistance mechanisms associated with altered intracellular distribution of anticancer agents. Pharmacol Ther 2000, 85:217-29.

21. Larsen AK, Skladanowski A: Cellular resistance to topoisomerase-targeted drugs: from drug uptake to cell death. Biochim Biophys Acta 1998, 1400:257-74.

22. Kern MA, Helmbach H, Artuc M, Karmann D, Jurgovsky K, Schadendorf D: Human melanoma cell lines selected in vitro displaying various levels of drug resistance against Cisplatin, fotemustine, vindesine or Etoposide: modulation of proto-oncogene expression. Anticancer Res 1997, 17:4359-70.

23. Spitz DR, Kinter MT, Roberts RJ: Contribution of increased glutathione content to mechanisms of oxidative stress resistance in hydrogen peroxide resistant hamster fibroblasts. J Cell Physiol 1995, 165:600-9.

24. Spitz DR, Li GC: Heat-induced cytotoxicity in H2O2-resistant Chinese hamster fibroblasts. J Cell Physiol 1990, 142:255-60.

25. Spitz DR, Phillips JW, Adams DT, Sherman CM, Deen DF, Li GC: Cellular resistance to oxidative stress is accompanied by resistance to Cisplatin: the significance of increased catalase activity and total glutathione in hydrogen peroxide-resistant fibroblasts. J Cell Physiol 1993, 156:72-9.

26. Steck PA, Pershouse MA, Jasser SA, Yung WK, Lin H, Ligon AH, Langford LA, Hattier T, Davis T, Frye C, Hu R, Swedlund B, Teng DH, Tavtigian SV: Identification of a candidate tumour suppressor gene, MMAC1, at chromosome $10 \mathrm{q} 23.3$ that is mutated in multiple advanced cancers. Nat Genet 1997, 15:356-362.

27. Li J, Yen C, Liaw D, Podsypanina K, Bose S, Wang SI, PuC J, Miliaresis C, Rodgers L, McCombie R, Bigner SH, Giovanella BC, Ittmann M, Tycko B, Hibshoosh H, Wigler MH, Parsons R: PTEN, a putative protein tyrosine phosphatase gene mutated in human brain, breast, and prostate cancer. Science 1997, 275:1943-1947.

28. Wang SI, PuC J, Li J, Bruce JN, Cairns P, Sidransky D, Parsons R: PTEN, a putative protein tyrosine phosphatase gene mutated in human brain, breast, and prostate cancer. Cancer Res 1997, 57:4183-4186. 
29. Guldberg P, thor Straten P, Birck A, Ahrenkiel V, Kirkin AF, Zeuthen J: Disruption of the MMAC1/PTEN gene by deletion or mutation is a frequent event in malignant melanoma. Cancer Res 1997, 57:3660-3663.

30. Cairns P, Okami K, Halachmi S, Halachmi N, Esteller M, Herman JG, Jen J, Isaacs WB, Bova GS, Sidransky D: Frequent inactivation of PTEN/MMAC1 in primary prostate cancer. Cancer Res 1997, 57:4997-5000.

31. Gravina G, Biordi L, Martella F, Flati V, Ricevuto E, Ficorella C, Tombolini V, Festuccia C: Epigenetic modulation of PTEN expression during antiandrogenic therapies in human prostate cancer. International Journal of Oncology 2009, 35:1133-9.

32. Soria JC, Lee HY, Lee Jl, Wang L, Issa JP, Kemp BL, Liu DD, Kurie JM, Mao L, Khuri FR: Lack of PTEN Expression in Non-Small Cell Lung Cancer Could Be Related to Promoter Methylation. Clin Cancer Res 2002, 8:1178-1184.

33. Whang YE, Wu X, Suzuki $H$ : Inactivation of the tumor suppressor PTENyMMAC1 in dvanced human prostate cancer through loss of expression. Proc Natl Acad Sci 1998, 95:5246-5250.

34. Davies MA, Koul D, Dhesi H, Berman R, McDonnell TJ: Regulation of AKT/ PKB activity, cellular growth, and apoptosis in prostate carcinomacells by MMAC/PTEN. Cancer Res 1999, 59:2551-2556.

35. Festuccia C, Gravina GL, D’Alessandro AM, Muzi P, Millimaggi D: Azacitidine improves antitumor effects of docetaxel and cisplatin in aggressive prostate cancer models. Endocr Relat Cancer 2009, 16:401-413.

36. Tanaka Motoyoshi, Koul Dimpy, Davies AMichael, Liebert Monica, Steck APeter, Grossman HBarton: MMAC1/PTEN inhibits cell growth and induces chemosensitivity to doxorubicin in human bladder cancer cells. Oncogene 2000, 19:5406-5412.

37. Fujiwara T, Grimm EA, Mukhopadnyay T, Zhang WW: Induction of chemosensitivity in human lung cancer cells in vivo by adenovirusmediated transfer of the wild type p53 gene. Cancer Res 1994, 54:2287-2291.

38. Ogawa N, Fujiwara T, Kagawa S: Novel combination therapy for human colon cancer with adenovirus-mediated wild-type p53 gene transfer and DNA-damaging chemotherapeutic agent. Int J Cancer 1997, 73:367-70.

39. Gurnani M, Lipari P, Dell J, Shi B, Nielsen LL: Adenovirus-mediated p53 gene therapy has greater efficacy when combined with chemotherapy against human head-neck, ovarian, prostate, and breast cancer. Cancer Chemother Pharmacol 1999, 44:143-151.

40. Thoretsky JA, Takar M, Eskenazi AE, Frantz CN: Phosphoinositide 3hydroxide kinase blockade enhances apoptosis in the Ewing's sarcoma family tumors. Cancer Res 1999, 59:5745-50.

41. Wan X, Li J, Lu X: PTEN augments doxorubicin-induced apoptosis in PTEN-null Ishikawa cells. Int J Gynecol Cancer 2007, 17:808-812.

42. Mayo LD, Dixon JE, Durden DL, Tonks NK, Donner DB: PTEN protects p53from Mdm2 and sensitizes cancer cells to chemotherapy. J Biol Chem 2002, 277:5484-9.

43. Green SK, Frankel A, Kerbel RS: Adhesion-dependent multicellular drug resistance. Anti-Cancer Drug Design 1999, 14:153-68.

44. St Croix B, Rak JW, Kapitain S, Sheehan C, Graham CH, Kerbel RS: Reversal by hyaluronidase of adhesion-dependent multicellular drug resistance in mammary carcinoma cells. J Natl Cancer Inst 1996, 88:1285-96.

45. St Croix B, Florenes VA, Rak JW, Flanagan M, Bhattacharya N, Slingerland JM, Kerbel RS: Impact of the cyclin dependent kinase inhibitor p27Kip1 on adhesion-dependent resistance of tumor cells to anticancer agents. Nat Med 1996, 2:1204-10.

46. St Croix B, Sheehan C, Rak JW, Florenes VA, Slingerland JM, Kerbel RS: Ecadherin-dependent growth suppression is mediated by the cyclin dependent kinase inhibitor p27KIP1. J Cell Biol 1998, 142:557-71.

47. Green SK, Francia G, Isidoro C, Kerbel RS: Anti-adhesive antibodies targeting E-cadherin sensitize multicellular tumor spheroids to chemotherapy in vitro. Mol Cancer Ther 2004, 3:149-59.

48. Teicher BA, Herman TS, Holden SA, Wang YY, Pfeffer MR, Crawford JW Frei E: Tumor resistance to alkylating agents conferred by mechanisms operative only in vivo. Science 1990, 247:1457-61.

49. Youn CK, Cho HJ, Kim SH, Kim HB, Kim MH, Chang IY, Lee JS, Chung MH, $\mathrm{Hahm} \mathrm{KS}$, You HJ: Bcl-2 expression suppresses mismatch repair activity through inhibition of E2F transcriptional activity. Nat Cell Biol 2005, 7:137-47.

50. Kobayashi H, Man S, Kapitain SJ, Teicher BA, Kerbel RS: Acquired multicellular-mediated resistance to alkylating agents in cancer. Proc Natl Acad Sci USA 1993, 90:3294-8.
51. Jain RK: Delivery of novel therapeutic agents in tumors: physiological barriers and strategies. J Natl Cancer Inst 1989, 81:570-6.

52. Bindra RS, Schaffer PJ, Meng A, Woo J, Måseide K, Roth ME, Lizardi P, Hedley DW, Bristow RG, Glazer PM: Down-regulation of Rad51 and decreased homologous recombination in hypoxic cancer cells. Mol Cell Biol 2004, 24:8504-18.

53. Plumb JA, Strathdee G, Sludden J, Kaye SB, Brown R: Reversal of drug resistance in human tumor xenografts by $2 \mathrm{~V}$-deoxy-5azacytidineinduced demethylation of the hMLH1 gene promoter. Cancer Res 2000, 60:6039-44.

54. Chan AT, Tao Q, Robertson KD, Flinn IW, Mann RB, Klencke B, Kwan WH, Leung TW, Johnson PJ, Ambinder RF: Azacitidine induces demethylation of the Epstein-Barr virus genome in tumors. J Clin Oncol 2004, 22:1373-81.

55. Esteller M, Hamilton SR, Burger PC, Baylin SB, Herman JG: Inactivation of the DNArepair geneO6-methylguanine-DNA methyltransferase by promoter hypermethylation is a common event in primary human neoplasia. Cancer Res 1999, 59:793-797.

56. Esteller M, Herman JG: Generating mutations but providing chemosensitivity: the role of O6-methylguanine DNA methyltransferase in human cancer. Oncogene 2004, 23:1-8.

57. Hermann A, Gowher $H$, Jeltsch A: Biochemistry and biology of mammalian DNA methyltransferases. Cell Mol Life Sci 2004, 61:2571-2587.

58. Bae SI, Lee HS, Kim SH, Kim WH: Inactivation of O6-methylguanine-DNA methyltransferase by promoter $\mathrm{CpG}$ island hypermethylation in gastric cancers. Br J Cancer 2002, 86:1888-1892.

59. Danam RP, Howell SR, Brent TP, Harris LC: Epigenetic regulation ofO6methylguanine-DNA methyltransferase gene expression by histone acetylation and methyl-CpG binding proteins. Mol Cancer Ther 2005 4:1-69.

60. Wang W, Huper G, Guo Y, Murphy SK, Olson JA Jr, Marks JR: Analysis of methylation sensitive transcriptome identifies GADD45a as a frequently methylated gene in breast cancer. Oncogene 2005, 24:705-2714.

61. Michel B, Flores MJ, Viguera E, Grompone G, Seigneur M, Bidnenko V: Rescue of arrested replication forks by homologous recombination. Proc Natl Acad Sci USA 2001, 98:8181-8.

62. McGlynn P, Lloyd RG: Recombinational repair and restart of damaged replication forks. Nat Rev Mol Cell Biol 2002, 3:859-70.

63. Szostak JW, Orr-Weaver TL, Rothstein RJ, Stahl FW: The doublestrand-break repair model for recombination. Cell 1983, 33:25-35.

64. Fishman-Lobell J, Rudin N, Haber JE: Two alternative pathways of doublestrand break repair that are kinetically separable and independently modulated. Mol Cell Biol 1992, 12:1292-303.

65. Burma S, Chen BP, Murphy M, Kurimasa A, Chen DJ: ATM phosphorylates histone $\mathrm{H} 2 \mathrm{AX}$ in response to DNA double-strand breaks. J Biol Chem 2001, 276:42462-7.

66. Rothkamm K, Kruger I, Thompson LH, Lobrich M: Pathways of DNA double-strand break repair during the mammalian cell cycle. Mol Cell Biol 2003, 23:5706-15.

67. Durocher D, Jackson SP: DNA-PK, ATM and ATR as sensors of DNA damage: variations on a theme? Curr Opin Cell Biol 2001, 13:225-31.

68. Roos WP, Kaina B: DNA damage-induced cell death by apoptosis. Trends Mol Med 2006, 12:440-50.

69. Kurz EU, Douglas P, Lees-Miller SP: Doxorubicin activates ATM dependent phosphorylation of multiple downstream targets in part through the generation of reactive oxygen species. J Biol Chem 2004, 279:53272-81.

70. Kiziltepe T, Hideshima T, Catley L, Raje N, Yasui H: 5-Azacytidine, a DNA methyltransferase inhibitor, induces ATR-mediated DNA double-strand break responses, apoptosis, and synergistic cytotoxicity with doxorubicine and bortezomib against multiple myeloma cells. Mol Cancer Ther 2007, 6:1718-1727.

71. Taylor WR, Stark GR: Regulation of the G2/M transition by $\mathrm{p} 53$. Oncogene 2001, 20:1803-15.

72. Wichmann A, Jaklevic $B$, Su $\Pi$ : lonizing radiation induces caspase dependent but Chk2- and p53-independent cell death in Drosophila melanogaster. Proc Natl Acad Sci USA 2006, 103:9952.

73. Aliouat-Denis CM, Dendouga N, Van den Wyngaert I, Goehlmann H, Steller U, van de Weyer I, Van Slycken N, Andries L, Kass S, Luyten W, Janicot M, Vialard JE: p53-independent regulation of p21Waf1/Cip1 expression and senescence by Chk2. Mol Cancer Res 2005, 3:627-34.

74. Pepper CJ, Hambly RM, Fegan CD, Delavault P, Thurston DE: The novel sequence-specific DNA cross-linking agent SJG-136 (NSC 694501) has 
potent and selective in vitro cytotoxicity in human B-cell chronic lymphocytic leukemia cells with evidence of a p53-independent mechanism of cell kill. Cancer Res 2004, 64:6750-5.

75. Tse AN, Schwartz GK: Potentiation of cytotoxicity of topoisomerase in poison by concurrent and sequential treatment with the checkpoint inhibitor UCN-01 involves disparate mechanisms resulting in either p53independent clonogenic suppression or p53-dependent mitotic catastrophe. Cancer Res 2004, 64:6635-44.

76. Chai Guolin, Li Lian, Zhou Wen, Wu Lipeng, Zhao Ying, Wang Donglai, Lu Shaoli, Yu Yu, Wang Haiying, McNutt AMichael, Hu Ye-Guang, Chen Yingai, Yang Yang, Wu Xin, Otterson AGregory, Zhu Wei-Guo: HDAC Inhibitors Act with 5-aza-2'-Deoxycytidine to Inhibit Cell Proliferation by Suppressing Removal of Incorporated Abases in Lung Cancer Cells. PLoS One 2008, 3:3412-20.

77. Nebbioso A, Clarke N, Voltz E, Germain E, Ambrosino C, Bontempo P, Alvarez R, Schiavone EM, Ferrara F, Bresciani F, Weisz A, de Lera AR, Gronemeyer H, Altucci L: Tumor-selective action of HDAC inhibitors involves TRAIL induction in acute myeloid leukemia cells. Nat Med 2005, 11:77-84.

78. Xu J, Zhou JY, Tainsky MA, Wu GS: Evidence that Tumor Necrosis FactorRelated Apoptosis-Inducing Ligand Induction by 5-Aza-29-Deoxycytidine Sensitizes Human Breast Cancer Cells to Adriamycin. Cancer Res 2007, 67:1203-1211.

79. Wang Q, Wang X, Hernandez A, Hellmich MR, Gatalica Z, Evers BM: Regulation of TRAIL expression by the phosphatidylinositol 3-kinase/Akt/ GSK-3 pathway in human colon cancer cells. J Biol Chem 2002, 277:36602-10.

80. Fulda S, Kufer MU, Meyer E, van Valen F, Dockhorn-Dworniczak B, Debatin KM: Sensitization for death receptor- or drug-induced apoptosis by re-expression of caspase-8 through demethylation or gene transfer. Oncogene 2001, 20:5865-77.

81. Fulda S, Debatin KM: 5-Aza-29-deoxycytidine and IFN-gamma cooperate to sensitize for TRAIL-inducedapoptosis by upregulating caspase-8. Oncogene 2006, 25:5125-33.

82. Gomyo Y, Sasaki J, Branch C, Roth JA, Mukhopadhyay T: 5-aza-29deoxycytidine upregulates caspase-9 expression cooperating with p53induced apoptosis in human lung cancer cells. Oncogene 2004, 23:6779-87.

83. Nottoli T, Hagopian-Donaldson S, Zhang J, Perkins A, Williams T: AP-2-null cells disrupt morphogenesis of the eye, face, and limbs in chimeric mice. Proc Natl Acad Sci USA 1998, 95:13714-9.

84. Feng W, Williams T: Cloning and characterization of the mouse AP-2e gene: a novel family member expressed in the developing olfactory bulb. Mol Cell Neurosci 2003, 24:460-75.

85. Higler-Eversheim K, Moser M, Schorle H, Buettner R: Regulatory roles of AP-2 transcription factors in vertebrate development, apoptosis and cell cycle control. Gene 2000, 260:1-12.

86. McPherson LA, Loktev AV, Weigel RJ: Tumor suppressor activity of AP2a mediated through a direct interaction with p53. J Biol Chem 2002, 277:45028-33

87. Zeng YX, Somasundaram K, El-Deiry WS: AP2 inhibits cancer cell growth and activates p21WAF1/CIP1 expression. Nat Genet 1997, 15:28-32.

88. Wajapeyee N, Somasundaram K: Cell cycle arrest and apoptosis induction by activator protein $2 a$ (AP-2a) and the role of $p 53$ and p21WAF1/CIP1 in AP-2amediated growth inhibition. J Biol Chem 2003, 278:52093-101.

89. Zhang J, Brewer S, Huang J, Williams T: Overexpression of transcription factor AP-2a suppresses mammary gland growth and morphogenesis. Dev Biol 2003, 256:127-45.

90. Douglas DB, Akiyama Y, Carraway H: Hypermethylation of a small CpGuanine rich region correlates with loss of activator protein-2a expression during progression of breast cancer. Cancer Res 2004, 64:1611-20.

91. Anttila MA, Kellokoski JK, Moisio KI, Mitchell PJ, Saarikoski S, Syrjänen K, Kosma VM: Expression of transcription factor AP-2a predicts survival in epithelial ovarian cancer. Br J Cancer 2000, 82:1974-83.

92. Ropponen KM, Kellokoski JK, Pirinen RT, Moisio Kl, Eskelinen MJ, Alhava EM, Kosma VM: Expression of transcription factor AP-2 in colorectal adenomas and adenocarcinomas; comparison of immunohistochemistry and in situ hybridisation. J Clin Pathol 2001, 54:533-8.
93. Heimberger AB, McGary EC, Suki D, Ruiz M, Wang H, Fuller GN, Bar-Eli M: Loss of the AP-2a transcription factor is associated with the gradeof human gliomas. Clin Cancer Res 2005, 11:267-72.

94. Ruiz M, Pettaway C, Song R, Stoeltzing O, Ellis L, Bar-Eli M: Activator protein 2a inhibits tumorigenicity and represses vascular endothelial growth factortranscription in prostate cancer cells. Cancer Res 2004, 64:631-8.

95. Gershenwald JE, Sumner W, Calderone T, Wang Z, Huang S, Bar-Eli M: Dominant-negative transcription factor AP-2 augments SB-2 melanoma tumor growthin vivo. Oncogene 2001, 20:3363-75.

96. Dicato M, Duhem C, Pauly M, Ries F: Multidrug resistance: molecular and clinical aspects. Cytokines Cell Mol Ther 1997, 3:91-9.

97. Hunt CR, Sim JE, Sullivan SJ, Featherstone T, Golden W, Von Kapp-Herr C, Hock RA, Gomez RA, Parsian AJ, Spitz DR: Genomic instability and catalase gene amplification induced by chronic exposure to oxidative stress. Cancer Res 1998, 58:3986-92.

98. Bergelson $S$, Pinkus $R$, Daniel V: Intracellular glutathione levels regulate Fos/Jun induction and activation of glutathione S-transferase gene expression. Cancer Res 1994, 54:36-40.

99. Dewey WC: Arrhenius relationships from the molecule and cell to the clinic. Int J Hyperthermia 1994, 10:457-83.

100. Diamond DA, Parsian A, Hunt CR, Lofgren S, Spitz DR, Goswami PC, Gius D: Redox factor-1 (Ref-1) mediates the activation of AP-1 in HeLa and NIH 3T3 cells in response to heat shock. J Biol Chem 1999, 274:16959-64.

101. Kerppola T, Curran T: Transcription. Zen and the art of Fos and Jun. Nature 1995, 373:199-200.

102. Martins NM, Santos NA, Curti C, Bianchi ML, Santos AC: Cisplatin induces mitochondrial oxidative stress with resultant energetic metabolism impairment, membrane rigidification and apoptosis in rat liver. J Appl Toxicol 2007, 23:234-244.

103. Simons AL, Ahmad IM, Mattson DM, Dornfeld KJ: Spitz DR. 2-DeoxyDglucose combined with cisplatin enhances cytotoxicity via metabolic oxidative stress in human head and neck cancer cells. Cancer Res 2007, 67:3364-70.

104. Siitonen T, Alaruikka P, Mantymaa P, Savolainen ER, Kavanagh TJ, Krejsa CM, Franklin CC, Kinnula V, Koistinen P: Protection of acute myeloblastic leukemia cells against apoptotic cell death by high glutathione and gammaglutamylcysteine synthetase levels during etoposide-induced oxidative stress. Ann Oncol 1999, 10:1361-7.

105. Mairesse N, Bernaert D, Del Bino G, Horman S, Mosselmans R, Robaye B, Galand P: Expression of HSP27 results in increased sensitivity to tumor necrosis factor, etoposide, and $\mathrm{H} 2 \mathrm{O} 2$ in an oxidative stress-resistant cell line. J Cell Physiol 1998, 177:606-17.

106. Furuta $Y$, Hunter $N$, Barkley $T$, Hall E, Milas L: Increase in radioresponse of murine tumors by treatment with indomethacin. Cancer Res 1988, 48:3008-13.

107. lliakis G, Seaner R, Okayasu R: Effects of hyperthermia on the repair of radiation-induced DNA single- and double-strand breaks in DNA doublestrand break repair-deficient and repair-proficient cell lines. Int $J$ Hyperthermia 1990, 6:813-33.

108. Jurivich DA, Pachetti C, Qiu L, Welk JF: Salicylate triggers heat shock factor differently than heat. J Biol Chem 1995, 270:24489-95.

109. Jurivich DA, Sistonen L, Kroes RA, Morimoto Rl: Effect of sodium salicylate on the human heat shock response. Science 1992, 255:1243-5.

110. Bhushan A, Abramson R, Chiu JF, Tritton TR: Expression of c-fos in human and murine multidrug-resistant cells. Mol Pharmacol 1992, 42:69-74.

111. Dignam JD: Preparation of extracts from higher eukaryotes. Methods Enzymol 1990, 182:194-203.

112. Maity A, Kao GD, Muschel RJ, McKenna WG: Potential molecular targets for manipulating the radiation response. Int J Radiat Oncol Biol Phys 1997, 37:639-53.

113. Yao KS, Godwin AK, Johnson SW, Ozols RF, O'Dwyer PJ, Hamilton TC: Evidence for altered regulation of gamma-glutamylcysteine synthetase gene expression among cisplatin-sensitive and cisplatin-resistant human ovarian cancer cell lines. Cancer Res 1995, 55:4367-74.

114. Bradbury CM, Locke JE, Wei SJ, Shah S, Rene LM, Clemens RA, Roti Roti J, Horikoshi N, Gius D: Increased activator protein 1 activity as well as resistance to heat-induced radiosensitization, hydrogen peroxide, and cisplatin are inhibited by indomethacin in oxidative stress-resistant cells. Cancer Res 2001, 61:3486-92.

115. Mishra MV, Bisht K S, Sun L, Muldoon-Jacobs K, Awwad R, Kaushal A, Nguyen P, Huang L, Pennington JD, Markovina S, Bradbury CM, Gius D: 
DNMT1 as a Molecular Target in a Multimodality-Resistant Phenotype in Tumor Cells. Mol Cancer Res 2008, 6:243-249.

116. Qiu H, Yashiro M, Shinto O, Matsuzaki T, Hirakawa K: DNA methyltransferase inhibitor 5 -aza-CdR enhances the radiosensitivity of gastric cancer cells. Cancer Sci 2009, 1:181-188.

117. Santi DV, Norment A, Garrett CE: Covalent bond formation between a DNA-cytosine methyltransferase and DNA containing 5-azacytosine. Proc Natl Acad Sci USA 1984, 81:6993-7.

118. Friedman S: The irreversible binding of azacytosine-containing DNA fragments to bacterial DNA(cytosine-5)methyltransferases. J Biol Chem $1985,260: 5698-705$.

119. Gabbara S, Bhagwat AS: The mechanism of inhibition of DNA (cytosine-5)-methyltransferases by 5 -azacytosine is likely to involve methyl transfer to the inhibitor. Biochem J 1995, 307:87-92.

120. Friedman S, Som S: Induction of EcoRIl methyltransferase: evidence for autogenous control. J Bacteriol 1993, 175:6293-8.

121. Liu K, Wang YF, Cantemir C, Muller MT: Endogenous assays of DNA methyltransferases: evidence for differential activities of DNMT1, DNMT2, and DNMT3 in mammalian cells in vivo. Mol Cell Biol 2003, 23:2709-19.

122. Juttermann R, Li E, Jaenisch R: Toxicity of 5-aza-2deoxycytidine to mammalian cells is mediated primarily by covalent trapping of DNA methyltransferase rather than DNA demethylation. Proc Natl Acad Sci USA 1994, 91:11797-801.

123. Ferguson AT, Vertino PM, Spitzner JR, Baylin SB, Muller MT, Davidson NE: Role of estrogen receptor gene demethylation and DNA methyltransferase DNA adduct formation in 5-aza-21-deoxycytidineinduced cytotoxicity in human breast cancer cells. J Biol Chem 1997, 272:32260-6.

124. Karpf AR, Moore BC, Ririe TO, Jones DA: Activation of the p53 DNA damage response pathway after inhibition of DNA methyltransferase by 5-aza-2-deoxycytidine. Mol Pharmacol 2001, 59:751-7.

125. Christman JK: 5-azacytidine and 5-aza-2-deoxycytidine as inhibitors of DNA methylation: mechanistic studies and their implications for cancer therapy. Oncogene 2002, 21:5483-95.

126. Barbe J, Gibert I, Guerrero R: 5-azacytidine: survival and induction of the SOS response in Escherichia coli K-12. Mutat Res 1986, 166:9-16.

127. Lal D, Som S, Friedman S: Survival and mutagenic effects of 5-azacytidine in Escherichia coli. Mutat Res 1988, 193:229-36.

128. Donninger H, Vos MD, Clark GJ: The RASSF1A tumor suppressor. J Cell Sci 2007, 120:3163-72.

129. Dammann R, Li C, Yoon JH, Chin PL, Bates S, Pfeifer GP: Epigenetic inactivation of a RAS association domain family protein from the lung tumour suppressor locus 3p21.3. Nat Genet 2000, 25:315-19.

130. Schildhaus HU, Krockel I, Lippert H, Malfertheiner P, Roessner A, SchneiderStock R: Promoter hypermethylation of p16INK4a, E-cadherin, O6-MGMT, DAPK and FHIT in adenocarcinomas of the esophagus, esophagogastric junction and proximal stomach. Int J Oncol 2005, 26:1493-500.

131. Herman JG, Latif F, Weng Y, Lerman MI, Zbar B, Liu S, Samid D, Gnarra JR, Linehan WM: Silencing of the VHL tumor-suppressor gene by DNA methylation in renal carcinoma. Proc Natl Acad Sci USA 1994, 91:9700-9704.

132. Alleman WG, Tabios RL, Chandramouli GV, Aprelikova ON, Torres-Cabala C, Mendoza A, Rogers C, Sopko NA, Linehan WM, Vasselli JR: The in vitro and in vivo effects of reexpressing methylated von Hippel-Lindau tumor suppressor gene in clear cell renal carcinoma with 5 -aza-20deoxycytidine. Clin Cancer Res 2004, 10:7011-7021.

133. Li Q, Ahuja N, Burger PC, Issa JP: Methylation and silencing of the Thrombospondin-1 promoter in human cancer. Oncogene 1999, 18:3284-3289.

134. Kissil JL, Feinstein E, Cohen O, Jones PA, Tsai YC, Knowles MA, Eydmann ME, Kimchi A: DAP-kinase loss of expression in various carcinoma and B-cell lymphoma cell lines: possible implications for role as tumor suppressor gene. Oncogene 1997, 15:403-407.

135. Katzenellenbogen RA, Baylin SB, Herman JG: Hypermethylation of the DAP-kinase CPG island is a common alteration in B-cell malignancies Blood 1999, 93:4347-4353.

136. Tang X, Sun SY, Wistuba II, Hong WK, Mao L: Hypermethylation of the deathassociated protein kinase promoter attenuates the sensitivity to TRAIL-induced apoptosis in human non-small cell lung cancer cells. Mol Cancer Res 2004, 2:685-691.
137. Reu FJ, Bae SI, Cherkassky L, Leaman DW, Lindner D, Beaulieu N, MacLeod AR, Borden EC: Overcoming resistance to interferon-induced apoptosis of renal carcinoma and melanoma cells by DNA demethylation. J Clin Oncol 2006, 24:3771-3779.

138. Reu FJ, Leaman DW, Maitra RR, Bae SI, Cherkassky L, Fox MW, Rempinski DR, Beaulieu N, MacLeod AR, Borden EC: Expression of RASSF1A, an epigenetically silenced tumor suppressor, overcomes resistance to apoptosis induction by interferons. Cancer Res 2006, 66:2785-2793.

139. Hopkins-Donaldson S, Bodmer JL, Bourloud KB, Brognara CB, Tschopp J, Gross N: Loss of caspase-8 expression in highly malignant human neuroblastoma cells correlates with resistance to tumor necrosis factorrelated apoptosis-inducing ligand-induced apoptosis. Cancer Res 2000, 60:4315-4319.

140. Fulda S, Kufer MU, Meyer E, van Valen F, Dockhorn-Dworniczak B, Debatin KM: Sensitization for death receptor- or drug-induced apoptosis by re-expression of caspase-8 through demethylation or gene transfer. Oncogene 2001, 20:5865-5877.

141. Eramo A, Pallini R, Lotti F, Sette G, Patti M, Bartucci M, Ricci-Vitiani L, Signore M, Stassi G, Larocca LM, Crino L, Peschle C, De Maria R: Inhibition of DNA methylation sensitizes glioblastoma for tumor necrosis factorrelated apoptosis-inducing ligand mediated destruction. Cancer Res 2005, 65:11469-11477.

142. Sen R, Baltimore D: Inducibility of kappa immunoglobulin enhancerbinding protein NF-kappa B by a posttranslational mechanism. Cell 1986, 47:921-928.

143. Criswell T, Leskov K, Miyamoto S, Luo G, Boothman DA: Transcription factors activated in mammalian cells after clinically relevant doses of ionizing radiation. Oncogene 2003, 22:5813-5827.

144. Jung M, Dritschilo A: NF-kappa B signaling pathway as a target for human tumor radiosensitization. Semin Radiat Oncol 2001, 11:346-351.

145. Orlowski RZ, Baldwin AS Jr: NF-kappaB as a therapeutic target in cancer. Trends Mol Med 2002, 8:385-389.

146. Khong T, Sharkey J, Spencer A: The effect of azacitidine on interleukin-6 signaling and nuclear factor- $\mathrm{kB}$ activation and its in vitro and in vivo activity against multiple myeloma. Haematologica 2008, 93:860-869.

147. Sharkey J, Khong T, Spencer A: PKC412 demonstrates JNK-dependent activity against human multiple myeloma cells. Blood 2006, 109:1712-9.

148. Mitsiades N, Mitsiades CS, Richardson PG, Poulaki V, Tai YT, Chauhan D, Fanourakis G, Gu X, Bailey C, Joseph M, Libermann TA, Schlossman R, Munshi NC, Hideshima T, Anderson KC: The proteasome inhibitor PS-341 potentiates sensitivity of multiple myeloma cells to conventional chemotherapeutic agents: therapeutic applications. Blood 2003, 101:2377-80.

149. Martin-Oliva D, Aguilar-Quesada R, O'valle F, Munoz-Gamez JA, MartinezRomero R, Garcia Del Moral R, Ruiz de Almodóvar JM, Villuendas R, Piris MA, Oliver FJ: Inhibition of poly(ADP-ribose) polymerase modulates tumorrelated gene expression, including hypoxia-inducible factor-1 activation, during skin carcinogenesis. Cancer Res 2006, 66:5744-5756.

150. Vo QN, Kim WJ, Cvitanovic L: The ATM gene is target for epigenetic silencing in locally advanced breast cancer. Oncogene 2004, 23:9432-9437.

151. Kim WJ, Vo QN, Shrivastav M, Lataxes TA, Brown KD: Aberrant methylation of the ATM promoter correlates with increased radiosensitivity in a human colorectal tumor cell line. Oncogene 2002, 21:3864-3871.

152. Das P: Singal R DNA methylation and cancer. J Clin Oncol 2004, 22:4632-4642.

153. Dunn BK: Hypomethylation: one side of a larger picture. Ann N Y Acad Sci 2003, 983:28-42.

154. Ehrlich M: DNA methylation in cancer: too much, but also too little. Oncogene 2002, 21:5400-5413.

155. Gaudet F, Hodgson JG, Eden A, Jackson-Grusby L, Dausman J: Induction of tumors in mice by genomic hypomethylation. Science 2003, 30:0:489-492.

156. Nishigaki M, Aoyagi K, Danjoh I, Fukaya M, Yanagihara K: Discovery of aberrant expression of R-RAS by cancer-linked DNAhypomethylation in gastric cancer using microarrays. Cancer Res 2005, 65:2115-2124.

157. Lutz W, Leon J, Eilers M: Contributions of Myc to tumorigenesis. Biochimica et Biophysica Acta (BBA) 2002, 1602(1):61-71.

158. Wang J, Whang H, Li Z, Wu Q: c-Myc is required for maintenance of glioma cancer stem cells. PLOS ONE 2008, 3:e3769.

159. Jupin P, Heber AO, Littelwood T, Evan G: C-Myc-induced sensitization to apoptosis is mediated through cytocrome c release. Genes Dev 1999, 13:1367-1381. 
160. Bucci B, D’Agnano I, Amendola D, Citti A: Myc down-regulation sensitizes melanoma cells to radiotherapy by inhibiting $\mathrm{MLH} 1$ and $\mathrm{MSH} 2$ mismatch repair proteins. Clin Cancer Res 2005, 11(7):2756-2767.

161. Fang JY, Yang L, Zhu HY, Chen YX, Lu J, Lu R: 5-Aza-2'-deoxycitidine indices demethylation and up-regulates transcription of p16INK4A gene in human gastric cancer cell lines. Chin Med J (Engl) 2009, 117(1):99-103.

162. Heller G, Schmidt WM, Ziegler B, Holzer S, Mullauer L: Genome-wide transcriptional response to 5-Aza-2'-deoxycitdine and tricostatin $A$ in multiple myeloma cells. Cancer Res 2008, 68(1):44-54.

163. Eden A, Gaudet F, Waghmare A, Jaenisch R: Chromosomal instability and tumors promoted by DNA hypomethylation. Science 2003, 300:455.

164. Yang AS, Estecio MR, Garcia-Manero G, Kantarjian HM, Issa JP: Comment on "Chromosomal instability and tumors promoted by DNA hypomethylation" and "Induction of tumors in mice by genomic hypomethylation". Science 2003, 302:1153.

165. [Http://www.vidaza.com/patient/default.aspx].

166. Dagon ${ }^{\circledast}$ (decitabine for injection). [http://www.supergen.com/]

167. Cheng JC, Yoo CB, Weisenberger DJ, Chuang J, Wozniak C, Liang G, Marquez VE, Greer S, Orntoft TF, Thykjaer T, Jones PA: Preferential response of cancer cells to zebularine. Cancer Cell 2004, 6:151-158.

168. Karpf AR, Peterson PW, Rawlins JT, Dalley BK: Inhibition of DNA methyltransferase stimulates the expression of signal transduction and activator transcription 1,2 and 3 genes in colon tumor cells. Proc Natl Acad Sci 1999, 96:14007-1412.

169. Karpf AR, Lasek AW, Ririe TO, Hanks AN: Limited gene activation in tumor and normal epithelial cells treated with the DNA methyltransferase inhibitor 5-Aza-2'-deoxycytidine. Molecular Parmacology 2004, 65:18-27.

170. Motegi K, Azuma M, Tamatani T, Ashida Y, Sato M: Expression of aquaporin-5 and fluid secretion from immortalized human salivary gland cells by treatment with 5-Aza2'-deoxycytidine: a possibility for improvement of xerostomia in patients with Sjogren syndrome. Lab Investigation 2005, 85:342-353.

171. Benyon RC, Arthur MJ: Extracellular matrix degradation and the role of hepatic stellate cells. Semin Liver Dis 2001, 21:373-384.

172. Hazra S, Xiong S, Wang J: Peroxisome proliferator-activated receptor gamma induces a phenotypic switch from activated to quiescent hepatic stellate cells. J Biol Chem 2004, 27(9):11392-11401.

173. Mann J, Oakley F, Akiboye F, Elsharkawy A, Thorne AW, Mann DA: Regulation of myofibroblast transdifferentiation by DNA methylation and MePC2: implication for wound healing and fribrinogenesis. Cell Death and Differentiation 2007, 14:275-285.

174. Liberto M, Cobrinik D: Growth factor-dependent induction of p21CIP1 by the green tea polyphenol, epigallocatechin gallate. Cancer Lett 2000, 154:151-161.

175. Sang S, Hou Z, Lambert JD, Yang CS: Redox Properties of Tea Polyphenols and Related Biological Activities. Antioxidants \& Redox Signaling 2005, 7:1704-1714.

176. Lambert JD, Sang S, Yang CS: Possible Controversy over Dietary Polyphenols: Benefits vs Risks. Chem Res Toxicol 2007, 20:583-585.

177. Sang S, Lambert JD, Hong J, Tian S, Lee MJ, Stark RE, Ho CT, Yang CS: Synthesis and Structure Identification of Thiol Conjugates of (-)-Epigallocatechin Gallate and Their Urinary Levels in Mice. Chem Res Toxicol 2005, 18:1762-176.

178. Sang S, Hou Z, Lambert JD, Yang CS: Redox Properties of Tea Polyphenols and Related Biological Activities. Antioxidants \& Redox Signaling 2005, 7:1704-1714.

179. Isbrucker RA, Edwards JA, Wolz E, Davidovich A, Bausch J: Safety studies on epigallocatechin gallate (EGCG) preparations. Part 2: dermal, acute and short-term toxicity studies. Food Chem Toxicol 2006, 44:636-650.

180. Yamamoto T, Hsu S, Lewis J, Wataha J: Green Tea Polyphenol Causes Differential Oxidative Environments in Tumor versus Normal Epithelial Cells. Journal of Pharmacology and Experimental therapeutics 2003, 307:230-237.

181. Yang CS, Lee MJ, Chen L: Human salivary tea catechin levels and catechin esterase activities: implication in human cancer prevention studies. Cancer Epidemiol Biomarkers Prev 1999, 8:83-89.

182. Yamamoto T, Hsu S, Lewis J, Wataha J: Green Tea Polyphenol Causes Differential Oxidative Environments in Tumor versus Normal Epithelial Cells. Journal of Pharmacology and Experimental therapeutics 2003, 307:230-237.
183. Pohlmann P, DiLeone LP, Cancella Al, Caldas AP: Phase II trial of cisplatin plus decitabine, a new DNA hypomethylating agent, in patients with advanced squamous cell carcinoma of the cervix. Am J Clin Oncol 2002, 25:496-501.

184. Tikoo K, Yunus Ali I, Gupta J, Gupta C: 5-Azaytidine prevents Cisplatin induced nephrotoxicity and potentiates anticancer activity of Cisplatin by involving inhibition of metallothionenin, PAKT and DNMT1 expression in chemical induced cancer rats. Toxicology Letters 2009, 191:158-166.

185. Qui H, Hashimiro M, Shinto O, Matsuzaki T, Hirakawa K: DNA methyltransferase inhibitor 5-Aza-CdR enhances the radiosensitivity of gastric cancer cells. Cancer Sci 2009, 100:181-188.

186. Santi DV, Garret CE, Barr Pj: On the mechanism of inhibition of DNA cytosine methyltransferase by cytosine anlogs. Cell 1983, 33:9-10.

187. Christman JK: 5-azacytidine and 5-Aza-2'deoxycytidine as inhibitors of DNA methylation: mechanistic studies and their implications for cancer therapy. Oncogene 2002, 21:5483-5495.

188. Karpf AR, Moore BC, Ririe TO, Jones DA: Activation of the p53 DNA damage response pathway after inhibition of DNA methyltransferase by 5-Aza-2'-deoxycytidine. Mol Pharmacol 2001, 59:751-757.

189. Neylon C, Kralicek AV, Hill TM, Dixon NE: Replication termination in Escherichia coli: structure and antihelicase activity of the Tus-Ter complex. Microbiol Mol Biol Rev 2005, 69:501-526.

190. Siaglotti L, Fratta E, Coral S, Cortini E, Covre A, Nicolay HY, Anzalone L, Pezzani L, Di Giacomo AM, Fonsatti E, Coalizzi F, Altomonte M, Calbrò L, Maio M: Epigenetic Drugs as Pleiotropic Agents in Cancer Treatment: Biomolecular Aspects and Clinical Applications. J Cell Physiol 2007 212:330-344.

191. Mund C, Brueckner B, Lyko F: Reactivation of Epigenetically Silenced Genes by DNA Methyltransferase Inhibitors: Basic Concepts and Clinical Applications. Epigenetics 2006, 1:1, 7-13.

192. Griffiths EA, Gore SV: DNA Methyltransferase and Histone Deacetylase Inhibitors in the Treatment of Myelodysplastic Syndromes. Semin Hematol 2008, 45(1):23-30.

doi:10.1186/1476-4598-9-305

Cite this article as: Gravina et al.: Biological rationale for the use of DNA methyltransferase inhibitors as new strategy for modulation of tumor response to chemotherapy and radiation. Molecular Cancer 2010 9:305.

\section{Submit your next manuscript to BioMed Central and take full advantage of:}

- Convenient online submission

- Thorough peer review

- No space constraints or color figure charges

- Immediate publication on acceptance

- Inclusion in PubMed, CAS, Scopus and Google Scholar

- Research which is freely available for redistribution

Submit your manuscript at www.biomedcentral.com/submit
Biomed Central 